\title{
Contractual networks: an organizational model to reduce the competitive disadvantage of small and medium enterprises (SMEs) in Europe's less developed regions. A survey in southern Italy
}

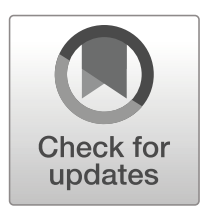

\author{
Patrizia Pastore $^{1}$ (D) $\cdot$ Antonio Ricciardi ${ }^{1}$ (D) $\cdot$ Silvia Tommaso ${ }^{1}$ (D)
}

Published online: 18 December 2019

(C) The Author(s) 2019

\begin{abstract}
Limitations faced by southern Italy's small enterprises due to their dimensions may be overcome by cooperation strategies and network contracts. The international literature has highlighted that effectively governed business networks appear to more successfully allow partner firms to improve their economic performance and survive over time. This paper combines qualitative and quantitative analyses to test the above hypothesis. It also analyses the performance of southern Italian firms that have joined business network contracts equipped with legal personality - the so called "reti soggetto" or "heavy contractual networks" (HCNs) - compared to firms participating in business networks based only on contractual agreements, devoid of legal personality- the so called "reti contratto" or "light contractual networks" (LCNs). Our findings demonstrate that only $13 \%$ of all registered business networks are in fact operative. Among the networks with legal personality, approximately $28 \%$ are active networks. A similar trend was observed for network contracts devoid legal personality: only $11 \%$ are truly active. Performance measures (including profitability, financial situation indicators, and debt sustainability) also differ for firms belonging to $\mathrm{HCN}$, compared to those belonging to LCN, in the years following the subscription of the network contract. Empirical analysis suggests that HCNs have significant positive effects on the performance of participant firms. We thus propose to verify the conditions that strengthen business networks in the south of Italy. We also recommend promoting the establishment of
\end{abstract}

Patrizia Pastore

patrizia.pastore@unical.it; http://www.unical.it/discag

Antonio Ricciardi

antonio.ricciardi@unical.it

Silvia Tommaso

silvia.tommaso@unical.it

1 Department of Business Administration and Law, University of Calabria, Ponte Pietro Bucci -

Cubo 3 C, 87036 Arcavacata di Rende (CS), Italy 
networks with juridical subjectivity. Such networks can be effective tools to strengthen the competitiveness of SMEs despite external diseconomies, which can markedly improve their creditworthiness.

Keywords Business networks · Business network contracts · Contractual networks · Networks with legal personality $\cdot$ SMEs $\cdot$ Less developed European regions

\section{Introduction}

In today's increasingly competitive global market, firm success is increasingly linked to the ability to undertake and manage collaborative strategies and alliances. Business networks can be an effective strategy in this regard. They bring together firms to exchange knowledge; to share industrial, commercial, and technological information, services or facilities; to share investments as well as risks; and to cooperate in product or market development. In doing so-whether they describe themselves as a partnership, a strategic alliance, an inter-organizational relationship, or simply as a business network-firms can increase their competitive advantages (Das and Teng 2000; Huggins 2001; Ahmad and Kitchen 2008; Håkansson et al. 2009; Cantele et al. 2016).

A business network can be defined as a system of firms, juridically autonomous yet linked by fiduciary relations or contracts. Such firms voluntarily share knowledge and experience (Lechner et al. 2006; Parker 2008) and may commit themselves to realizing conjoint investments as well as co-producing, co-marketing, and jointly pursuing research and product or market development (Huggins 2001; Ricciardi 2003). Generally, business networks originate with one or more (leading) firms that have the resources and leadership ability to organize and manage the network. They select partners (nodes) based on specific competencies, and everyone in the production process "does what they do best". The essence of these collaborative strategic networks is that several firms engage in a common project (Håkansson and Snehota 1995), exploiting their complementarity without losing their juridical, economic, or decisionmaking autonomy.

Business networks can lead to major benefits in terms of learning (BarNir and Smith 2002), business development processes (Verschoore et al. 2015; Lin and Lin 2016), innovation and technological improvements (Vanhaverbeke et al. 2009), and internationalization and competitive advantages (Lu and Beamish 2001; Fernhaber and Li 2013). Thus, the network organizational model is a preferred route to stimulating business development and economic growth at the international, national, and regional levels (Etzkowitz 2008; Johnson and Lundberg 2011; Cardoni 2012). Strategic business networks among interconnected firms are a vital component of firm strategy - particularly for SMEs - in today's complex, uncertain, and demanding environment.

By organizing into business networks, SMEs can obtain the advantages of large-size firms without exchanging holdings or engaging in consortia, mergers, and/or incorporation. In this way, SMEs avoid losing their classic attributes of flexibility and autonomy (Håkansson and Snehota 1995). By exploiting their complementarities, they can carry out common projects, and the individual SMEs within each network can gain competitive advantages. The network as a whole may also obtain collaborative competitive advantages (such as increased productivity, innovation capability, and 
profitability), which individual firms could otherwise pursue only by adapting their internal structures or developing more structured relationships. Thus, SMEs can grow-but in a less complex and more virtual way. Firms can also be partners in multiple business networks, "which can be formal or informal, structured or destructured, managed or not managed" (Cisi et al. 2016: V-65). Therefore, the relatively small size of an SME no longer constitutes an intermediary stage compared to a large enterprise. Instead, the SME is understood an autonomous entity capable of triggering unique development paths. Business network contracts often represent an evolution of pre-existing developed relationships among firms that have become more complex over time. Networks may change from informal and unplanned relationships to those that are planned and more structured. In these cases, partner firms may have strong ties compared to weak ties among firms involved in merely contractual networks (Hoang and Antoncic 2003).

This type of interaction among firms has gained attention at the European level since SMEs are the backbone of the European economy and represent an essential source of jobs (European Commission 2014). SMEs represented $98.8 \%$ of firms operating in the EU-28 non-financial business sector in 2016, and they employed $67 \%$ of the workforce. ${ }^{1}$ Nearly all $(93 \%)$ of these SMEs were micro enterprises employing less than 10 people (European Commission 2017: 6). Recognizing the economic, strategic, and social importance of micro-, small- and medium-sized firms, several policies and actions have been taken in their favour (including the Horizon 2020 Program and the Small Business ACT for Europe, 2011). These initiatives promote collaboration and business networks among firms, research consortia, and institutions inside and outside Europe. They aim to stimulate national and regional development across European countries and to actively benefit smaller firms by providing both direct and indirect financial and other types of support to firms willing to co-operate and establish networks (European Commission 2012).

The strategic and economic importance of these networks has also been recognised by the Italian legislature, which was the first amongst all European legislatures to regulate a specific, formal legal framework for a "contractual network" - contratto di rete (Law No. 33 of 9 April 2009; conversion of Legislative Decree No. 5 of 10 February 2009 and subsequent legislative and regulatory amendments). This framework allows for the formalization of various types of inter-firm cooperation. It also emphasizes the strategic nature of this organizational model, encouraging the establishment of new business networks (Ricciardi 2010; Ricciardi et al. 2014).

In this paper, "business networks" refer to the general category of collaborations in various degrees among micro-, small- and medium-sized enterprises whilst "contractual networks" $(\mathrm{CN})$ refers to the legal institution of "contractual business networks" under Italian law.

The Italian contractual network is a juridical-economic instrument designed and adopted in Italy to support and promote inter-firm cooperation processes. In particular, it aims to stimulate Italian firms (particularly those that are smaller and less structured) to jointly perform one or more of their respective business activities and to thereby

\footnotetext{
${ }^{1}$ There were an estimated 24.5 million SMEs in the European Union in 2017. The vast majority were microsized firms, employing fewer than nine people. Small firms, with 10-49 employees, comprised 1.42 million of the SMEs while 231,000 were medium-sized firms with 50-249 employees (European Commission, 27 August 2019).
} 
sustain and expand their "innovative capacity and competitiveness' on the domestic and international markets. The framework gives broad autonomy to the partner firms to negotiate, from defining the subject of the network contract to determining the type of collaboration (i.e., horizontal or vertical networks) and cooperation procedures. However, the Italian legislature's sui generis model regulates two different types of business network: light contractual networks (LCN), or rete-contratto, and heavy contractual networks (HCN), or rete-soggetto. Partners can choose between the two, adopting the type that best suits their specific legal and economic circumstances.

The LCN is characterized by a simplified organizational structure and single mandatory content according to which partner firms mutually agree to implement a shared framework programme; however, the acts performed in the execution of the business network programme produce their effects directly in the juridical-subjective spheres of the network participants. In this case, the ownership of assets, rights, obligations, and acts are due, proportionally, to the individual participating companies.

The HCN, instead, has a more complex structure (the provision of a separate dedicated fund ascribable to the network and the presence of a common management body). As such, it assumes an independent juridical relevance once the contract is registered in the Italian Business Register held by the Chambers of Commerce. In this case-and this is the distinctive aspect of the Italian model-the business network has its own legal personality, which is distinct from that of its individual members. The network's legal personality is independent with regard to mutual relationships among partners as well as to the relationships between the network as such and third parties. The network thus becomes an independent centre for rights and obligations and a separate taxable subject with its own VAT identification number.

This normative framework is intentionally flexible. It aims to promote collaboration and networking, particularly among smaller firms, allowing them to reach the critical mass necessary to support growth and innovative business development processes in a manner consistent with the strategic orientations of the European Union.

In the "Innovation and Competence" chapter of the 2011 revised Small Business Act, the European Commission recognised the Italian business network contract as one of the key best practices of network agreement models, which could stimulate other European legislators in this direction (OECD 2014: 117). Many Italian SMEs are also now part of complex, global value chains, contributing to the formation of their competitive advantages through flexible and diversified solutions. ${ }^{2}$

For the first time, to the best of our knowledge, this paper investigates the business network contracts phenomenon in Italy's southern regions (Abruzzo, Molise, Apulia, Campania, Basilicata, Calabria, Sicily, and Sardinia). These regions are similar to the

\footnotetext{
${ }^{2}$ According to the latest Istat Annual Report (2018: 13), the Italian production structure is characterized by a dense network of relationships among both informal and formal firms. "In 2017, more than half of all enterprises reported stable relationships with other companies. From a territorial point of view, "networking enterprises are more widespread in the North-east and less so in the South and Islands. Stable relations are on a scale ranging from the simplest, of a commercial nature, through "vertical" relations (order/sub-supply), to complex networks (marketing activities and shared services, innovation, research, etc.). The latter have quickly gained ground, involving more than $30 \%$ of companies in 2017 ... From a territorial point of view, networking firms are more widespread in the North and less so in the South and Islands, where network relationships with low interdependences are prevalent."
} 
European and Italian national contexts in that firms belonging to the SME category ${ }^{3}$ very often family-owned - are a salient feature and have a fundamental role in the economy.

Under both the EU Regional Policy and the Cohesion Policy for 2014-2020, southern Italy is recognised as one of the EU's underdeveloped areas. It demonstrates both intrinsic weaknesses - lacking infrastructure, services for firms and the public, and foreign direct investments - and socio-economic disparities compared to the more developed areas of the centre and north of Italy. Several indicators (average annual growth, unemployment rate, levels of innovation, and competitiveness) negatively characterize the region's development path (Bentivogli et al. 2013; Eurostat 2014; Svimez 2015). The competitiveness of southern Italy's SMEs is undermined by several other chronic problems such as:

- limited managerial competences and a lack of specialized professional skills (also due to significant migrations of graduated and skilled workers to other areas of the country or even abroad);

- difficulties related to generational turnover;

- limited financial resources, greater exposure to credit crunch risk, and the worst credit ratings assigned to them by banks;

- lower productivity and difficulties in exploiting technology; and.

- reduced ability to penetrate international markets (Bugamelli et al. 2000; Ricciardi 2003, 2010; Brandolini and Bugamelli 2009; Bugamelli et al. 2012; Eurostat 2017; Mediobanca-Unioncamere 2017).

Despite these limitations, SMEs have a low propensity for relationships and collaboration (Calignano and Hassink 2016). This paper views participation in contractual networks as a strategic alternative to the reluctance of southern Italy's SMEs to increase their scale (Rosenfeld 1996; Hanna and Walsh 2008; Altomonte and Ferri 2012; Ricciardi 2014).

Moreover, the resource-sharing aspect of contractual networks could represent a valuable opportunity to overcome the limits relating to the smaller size of firms in less developed areas such as the south of Italy. This could be considered "a practical and cost-saving way that partially compensates for the lack of infrastructure and service" (Cisi et al. 2016: V-77) and for the problems posed by their isolation.

Nearly all scholars agree that this approach can offer competitive advantages (Gulati and Higgins 2003; Zaheer and Bell 2005; Dooley et al. 2016), particularly in the form of positive returns from inter-firm cooperation and networking. However, it is more difficult to observe a direct relationship between networking and a firm's performance

\footnotetext{
${ }^{3}$ According to the Italian Statistic Yearbook 2018 from the Italian National Institute of Statistics, SMEs represented $99.9 \%$ of active firms out of 4.4 million firms in Italy in 2016 . SMEs employed $82 \%$ of workers in Italy (well above the EU average). A total of $95.2 \%$ were small businesses (maximum 9 employees), employing $45.3 \%$ of total employees. The average firm had 3.9 employees. Large firms (250 or more employees) accounted for $0.1 \%$ of the total number of firms and provided $20.6 \%$ of employment. In the southern regions, SMEs represented $83 \%$ of production, compared to the national average of $57 \%$. SMEs also provided $95 \%$ of all employment in the south, far exceeding the Italian average (Istat 2018:487). Very small firms are prevalent in the south of Italy. The enterprise landscape in this area is dominated by individual firms (approximately 1.2 million), micro-firms (approximately 125,000) and SMEs (approximately 27,000).
} 
since the latter is influenced by other variables. These variables include the network's size, the geographical dispersion and/or sectorial diversity of its members (Schoonjans et al. 2013; Cisi et al. 2018), the goals to be pursued, and the reputation of its members (Brand et al. 2018).

However, despite the economic downturn, according to the Intesa SanpoloMediocredito Italiano Observatory on Enterprise Networks (2014), Italian firms belonging to networks have achieved "a greater ability to maintain their gross operating margins, a better strategic positioning and, specifically in the manufacturing sector, a greater competitive ability".

This paper contributes to the literature and empirical research by investigating, on the one hand, how many business network contracts have been signed by Southern Italian firms (based on results from the database of RetImpresa, Confindustria's dedicated agency for business networks in Italy: www.retimpresa.it). It further explores how many of these contracts are actually operating and the features they present in terms of governance structure and organizational model (Fjeldstad et al. 2012; Ferraro et al. 2015; Ricciardi et al. 2018: 329). Interestingly, our analysis found that only 101 (13.0\%) of the 769 registered contractual networks in the south of Italy from 2010 to 2017 are actually operating. Among these, 26 are HCNs, equipped with legal personality (out of a total of 94), and 75 are LCNs, devoid of legal personality (out of a total of 675).

Our aim is to verify whether the legal regulation of network contracts in Italy has encouraged firms in the country's south to undertake collaborations and strategic alliances and to thus sign related network contracts. On the other hand, the paper analyses the performance of firms belonging to HCNs "with legal personality" and compares it with the performance of firms belonging to LCNs. This choice is based on the consideration, supported by the international literature (Williamson 1975; Storper and Harrison 1991; Oxley 1999; Fjeldstad et al. 2012; Ricciardi et al. 2014; Ferraro et al. 2015), that business networks that are considered a "subject of law" are more effectively governed and, therefore, work better-allowing partner firms to achieve better performance and survive over time.

The nature of this research is exploratory. Its main purpose is to determine whether stimulating the development of business network contracts in southern Italy could increase the competitiveness of local SMEs-and thus the region's competitiveness - in line with the strategic objectives of the EU Regional Policy and Cohesion Policy. Said contracts are formalized according to the regulatory framework established by Italian Law No. 122/2010, and its subsequent amendments and additions over time, to enhance its attractiveness and encourage its dissemination.

In the following section, we briefly review the literature on business networks and business performance as well as the typicality of Italian regulation of business network contracts. Next, we describe our methodology and discuss our findings. Our final remarks and suggestions for practical implications and future research are then provided.

\section{Theoretical framework and research questions}

There is a broad spectrum of literature on strategic business networks and how these affect firm competitiveness, in particular that of smaller firms (Kirby and Kaiser 2005). Over the past 30 years, business networks have been extensively studied from different perspectives in the theoretical and empirical research. 
Many studies have focused on the forms and characteristics of networks and alliances (Todeva 2006). Such studies have considered various dimensions, such as the presence of strategic planning processes, the presence of leading firms (Landsperger et al. 2012; Jenssen and Nybakk 2013), the degree of formalization of contractual arrangements, and the presence or absence of coordination mechanisms (Alter and Hage 1993). Another explored dimension has been "the level of cooperation required and the size of the network distinguishing between horizontal networks, with competitors sharing some special projects of innovation and strategic development to reach wider markets or implement internationalization projects, and vertical networks, in the form of supply chains among companies that operate in the same sector at different stages of production" (Cardoni 2012: 98; Tomlinson 2010).

Researchers have also emphasized the role of appropriate formal governance structures for business networks (Brass et al. 2004; Provan et al. 2007; Teng and Das 2008) and network management practices (Oliver and Ebers 1998). Other studies have deepened our understanding of features such as inter-organizational trust (Zaheer et al. 1998), which guarantees actions in the interest of collaboration or the motivations that lead firms to adopt cooperation strategies and their functioning (Axelrod 1984; Child and Faulkner 1998).

Consistent with the previous studies of the business networks phenomenon in Italy, this paper assumes that the effect of networking on performance can differ according to the varying characteristics of the network partners and to the specific features of the business network. According to Cai and Szeidl (2018), learning and partnering are active mechanisms that can improve firm performance. Cai and Szeidl randomized 2820 Chinese firms into small groups of firms whose owners/managers held monthly meetings for one year and into a "no-meetings" control group. They found that the meetings allowed exogenous business-relevant information to be shared. Learning from peers was also facilitated, and supplier-client matching improved. Consequently, firm revenue increased by $8.1 \%$. Profit, borrowing, and the number of partners also significantly increased.

This paper combines the theoretical frameworks of transaction cost economics (Williamson 1975, 2002; Powell 1990; Jarillo 1993) and resource-based perspectives that offer an innovative approach to the development and implementation of network strategies for SMEs (Wernerfelt 1984, 1995; Peteraf 1993; Meiseberg and Ehrmann 2013). The paper assumes that business networks can improve firm performance by reducing transaction costs (Lin and Lin 2016), providing them with dynamic capabilities (Nelson and Winter 1982; Barney 1991; Teece et al. 1997; Teece 2007) and external innovative resources and competencies in a flexible manner and at a reduced cost ( $\mathrm{Li}$ et al. 2015), and stimulating innovation and new product development (Mazzola et al. 2016). Business networks can thereby foster knowledge spillovers (Ramadani et al. 2017) and technological improvements (Vanhaverbeke et al. 2009).

The possibilities for using knowledge resources held by individual firms can be multiplied in accordance with the social capital approach (Tsai and Ghoshal 1998) thanks to: the presence of specialized firms (engaged in different stages of the value chain), access to all knowledge disseminated in the network, and social interaction among partners within the network (Fuentes et al. 2010; Fornoni et al. 2011). These elements constitute the structural dimension of social capital (Nonaka 1994; Rullani 2011). Trust is the relational dimension of social capital (Tsai and Ghoshal 1998: 464; 
Scarbrough et al. 2013). Linked to the continuous inter-firm exchange of resources, trust reduces the threat of opportunistic behaviour by the partners and has a significant effect on both product innovation and financial success (Baron and Markman 2003).

Per the international literature on the topic, the organizational network model enables networked firms, especially SMEs, to

- implement strategies and operate in markets with the competitiveness of a mediumlarge enterprise (Dyer and Singh 1998) without sacrificing their autonomy and flexibility (Gardet and Fraiha 2012; Laperche and Liu 2013);

- implement collective learning processes and reduce business uncertainty, benefiting from economies of scale without bearing the disadvantages of large size (Watson 2007, 2011; Li et al. 2015);

- achieve better economic performance (increased turnover and investments, reduction in costs and operational risk); and

- improve their creditworthiness compared to stand-alone enterprises (Geretto and Zanin 2017; Ricciardi and Ingarozza 2018). This is especially true if the network organization is stable, planned, and effectively governed and if banks are able to evaluate the relational system (Tommaso 2009; Pastore 2009; Ricciardi 2016). In this regard, the direct and indirect social ties within the network may reduce the problems of information asymmetry in the credit market (Shane and Cable 2002) and allow banks to more easily evaluate firms' reliability and risk as well as the quality of the projects to be financed.

SMEs hosted in business networks may also have easier access to global value chains and foreign markets (Accetturo et al. 2011; Giunta 2014; Agostino et al. 2015). By exploiting their complementarities, together they may reach the necessary critical mass to:

- achieve product and process innovations (Gulati and Higgins 2003; Zaheer and Bell 2005; Castaldi et al. 2015; Sorrentino et al. 2015; Schott and Jensen 2016) at lower costs (Cai and Szeidl 2018);

- capture valuable market opportunities (Lechner and Dowling 2003) and enter key markets (Laurell et al. 2017);

- $\quad$ significantly increase their productivity and develop high-range products in typical "Made in Italy" productions in accordance with the different and increasingly variable market requirements (Stoian et al. 2017).

Scholars have investigated the competitive advantage and performance of firms belonging to business networks (Huxham and Vangen 2005; Zineldin and Dodourova 2005). However, the literature does not discuss the definitions of performance within the network environment. Similarly, there is no shared general model on which to address performance measurement in business networks.

Despite the extensive literature on other aspects of the subject, performance measurement for business networks has received little attention in the existing scientific papers and empirical works (Franco-Santos et al. 2012; Keung and Shen 2012; Agostino and Arnaboldi 2015). The analyses are mainly theoretical or based on case studies (Mancini and Piscitelli 2018). However, Cisi et al. (2018) found a positive effect between participation in a business network and the gross margin ratios and 
exports of firms in a study of a large sample of Italian SMEs that signed business network contracts drawn up in accordance with Italian regulations. Nevertheless, no effects on profits were observed.

The ability to innovate is vital to support firms' economic activities (Wang et al. 2015), build or strengthen their global competitive advantage (Linton and Solomon 2017), and to ensure their survival (Löfsten 2016). In turn, innovation is determined by the ability to generate new knowledge and to use it (Drewniak and Karaszewski 2019) as well as to enter new technological domains (McEvily and Chakravarthy 2002; Cefis and Marsili 2005; Santarelli and Vivarelli 2007).

Network stability, competitiveness and efficiency are determined by various fundamental factors including the motivation for cooperation, the degree of trust and integration among the partners, the exchange of information and knowledge (Boisot 1998), the presence of planning systems and/or tools that define the "mission", the objectives to be pursued in the various stages of development of the aggregation, the resources to be used and the respective responsibilities, and the presence of a system of government or network manager that guarantees the effective control and coordination of activities and results (Nickerson and Zenger 2004; Gulati et al. 2005; De Man and Roijakkers 2009; Tresca 2016). In cases where planning and government systems are in effect, a longer average network survival is observed (Ricciardi et al. 2014). Under these conditions, the network can represent a valid solution to the dimensional problem of southern Italy's production system as it has been observed that it often evolves towards the specific situation of a heavy contractual network or a formal group of companies (Ricciardi 2016).

The first peculiarity of the Italian business network contract is that the networked firms remain completely autonomous, yet in the contract, they are required to define and describe their formally defined common objectives and the strategic and operating programme they intend to develop by jointly providing dedicated resources to achieve it.

A second distinctive aspect of the Italian model is that Italian law recognises, under particular compulsory conditions, a separate legal relevance to the business network contract as such. Therefore, the business network acquires its own legal personality/subjectivity, which is distinct from that of its individual members and independent of their mutual relationships as well as of the relationships between the network and third parties.

From a formal point of view, the participating firms have broad negotiating autonomy in defining the object of the business network contract; in determining duration, cooperation, and decision-making procedures; and in shaping the contract according to the strategic goals that the participants aim to pursue. ${ }^{4}$ Network activities operate on the market via a joint capital fund (made up of contributions from the partners and measured in accordance with the annual asset and liability position as a sort of network

\footnotetext{
${ }^{4}$ The law provides a composite framework where optional elements of the contract are accompanied by obligatory elements. The following elements must be present in the contract: the participants' data; the strategic objectives they intend to pursue; the type of activities that will be conducted collectively; the network plan, specifying the individual agreements and arrangements set for the realization of the common goal; the procedures that will assess progress towards said objectives; the common entity that is entrusted with the execution of the contract; and the provision of a mutual fund for the realization of the network's projects. The law also spells out the duration of the contract, the parties' rights and obligations, and the right to withdraw from the contract (Article 3, paragraph 4 of the Law of 9 April 2009 n. 33, as amended by the Law of 30 July 2010, n. 122).
} 
balance sheet). They operate through a joint body that is entitled to represent the business network in relationships with third parties and is responsible for managing - on behalf of the members - the execution of the contract, the single parties or the stages thereof (Cafaggi 2009: 31; Arrigo 2013; Tunisini et al. 2013). ${ }^{5}$

Nonetheless, the Italian legislature has provided a sui generis model that regulates two types of business network: a "simplified" business network contract, which is called rete contratto or a light contractual network (LCN), and a business network contract with autonomous legal personality, which is called rete soggetto or a heavy contractual network $(\mathrm{HCN})$. Partners can choose between the two, adopting the contract type that best suits their specific legal and economic circumstances (Ricciardi 2003, 2010, 2014; Pastore 2009; Tommaso 2009).

The LCN (rete contratto), in its simplified (or pure) form, is characterized by mandatory content and a "light" organizational structure according to which partner firms mutually agree to implement a shared common programme of activities (the business network programme). The network programme is an essential element characterizing the business network contract, which must contain the rights and obligations assumed by each participant and the ways by which to achieve the network's common purpose. It summarizes the participating firms' shared project. It also specifies the activities and investments required for the achievement of the planned goals, to be implemented by financial resources that are allocated to a separate, common patrimonial fund and managed by the joint body.

In this type of business network contract, the network as such does not acquire individual legal personality; it does not represent a new entity that differs from its member firms. Therefore, on the one hand, the joint body acts in the name of and on behalf of the individual partners of the network. Any acts carried out in the execution of the business network programme produce their effects directly on the juridicalsubjective spheres of the network's individual participants. In this case, the ownership of assets, rights, obligations, and acts are all proportionally due to the individual participating firms. On the other hand, the liability for the network's obligations (into which the joint body enters) weighs exclusively on the same fund, thereby fulfilling a limited liability arrangement for the partner firms (i.e., third parties may exercise their rights exclusively against the joint fund).

A network with an autonomous legal personality, referred to as an $\mathrm{HCN}$ (retesoggetto), has a more complex ("heavy") structure (Alberti 2012). This includes the presence of a common management body or a network manager as well as the provision of a separate patrimonial fund ascribable to the network. Legal subjectivity is reached only if, in the presence of the patrimonial autonomy and common managing committee, the contract is registered to the Italian Business Register (held by the Chambers of Commerce in the district where the main headquarters are located). Through such registration, the network acquires legal subjectivity and becomes the centre of rights and duties towards third parties. In this case, the network is a subject distinct from the firms that have signed the contract. It thus assumes obligations in its own right (as an independent centre for the assignment of rights

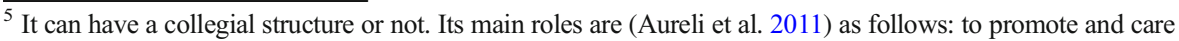
for the collective interests of the network, guaranteeing that the network follows the communal scope and eliminating or reducing abusive behaviors; to facilitate the exchange of information among the parties; and to reconcile the individual interests of the participants (it can also mediate between them).
} 
and responsibilities). From a taxation standpoint, the network becomes a taxable subject (see Revenue Agency Circular No. 20 / E of 18/06/2013). It can therefore exercise all the effects of business activities and be subject to bankruptcy procedures.

Regarding business network governance, a qualitative survey (described in the next paragraph) allowed us to detect respondents' perceptions of the willingness of firms and their representatives to cooperate and the frequency of meetings among the representatives of the network (participatory architecture); the stability and duration of the relationships among the firms involved and the presence of a management committee, a network manager, or other recognised leadership (organizational integration); the provision of a dedicated common patrimonial fund; consistency among the declared objectives, programmed activities, and duration of the contract (Ricciardi et al. 2018: 329); and the presence of specific mechanisms to prevent and resolve opportunistic behaviours (Fjeldstad et al. 2012; Ferraro et al. 2015).

In the first eight years since the business network contract law took effect, it has been observed that participation in business networks makes micro-, small-, and medium-sized firms more competitive (Dyer and Singh 1998). Networks help them to grow, improve their competitiveness, and achieve higher performance. However, the medium-to-longterm economic effects on participating firms have yet to be verified and analysed.

As argued by Ng and Rieple (2014: 448), firms that leverage their network relationships can reap positive effects in their performance. These include the strategic development of entrepreneurial ventures, financial growth, and valuable market opportunities (Lechner and Dowling 2003); growth in sales (Collins and Clark 2003), particularly in high-tech firms; and the opportunity to count on a common set of valuable knowledge and production skills (Lee et al. 2001; Teng 2005) that cannot be replicated by competitors (Prahalad 1993).

In accordance with the approach of Strategic Network Strategy Theory, this paper views business networks as systems of strategic inter-firm relationships based on longlasting collaborations. Such relationships are oriented towards the joint management of value creation processes that are carried out with the aim of acquiring and/or defending competitive advantages (Jarillo 1988).

The strategic dimension of organizational models based on network coordination led to the development of a stream of research devoted to the investigation of how participation in one or more networks affects business performance. At a conceptual level, merely belonging to a network can affect individual firm performance. However, as some scholars (Hoang and Antoncic 2003; Bodnaruk et al. 2013; Carini and Muzzi 2016) have argued, the contents of network relationships, governance and structure are vital strategic dimensions that should be taken into explicit consideration. These factors can help us estimate and understand the potential competitiveness of both networks and their member firms.

Taking the above into consideration, this paper proposes the first empirical investigation into the effects on performance of southern Italian firms that have signed one or more network contract over the period from 2011 to 2015.

Therefore, our first research question is as follows:

RQ. 1 Did the regulation of business network contracts in Italy through a law (2009) and its amendments (2010-2012) actually encourage southern Italian firms to collaborate and sign network contracts? 
With reference to the number of signed contracts, it is also interesting to investigate the presence or absence of conscious planning. This helps us ascertain whether the signed contracts represent the spontaneous formation of networks (bottom-up networks); planned and governed networks; or induced networks (top-down), which are originated on the basis of government incentives and tax breaks for subscriber firms. Our second research question is thus as follows:

RQ. 2 Are signed business network contracts actually operative, or are they mostly formal and signed only to benefit from their short-term advantages (such as fiscal benefits and/or public economic support)?

In response, we carried out a qualitative analysis to identify how many and which business networks (formalized through the signing of a contract) are actually active.

Based on the various studies arguing that cooperating network companies achieve better performance, our third research question is thus as follows:

RQ. 3 Do firms involved in HCNs achieve better performance than those involved in LCNs?

Taking into account the rich and diversified literature regarding the relationship between participation in business networks and firm performance (Gulati 1995), various accounting measures of performance have been selected to estimate the "network effect" on the performance of member firms (Franco 2011; Kawai 2012). Accounting performance measures were chosen for two reasons. First, economic and financial objectives are fundamental requirements for firm survival (Cantele and Vernizzi 2015). Second, these objectives are viewed as the most useful and accessible tools for measuring firm performance (Beamish and Lupton 2009; Baker 1992, 2000; Budde 2007; Cantele and Vernizzi 2015).

Amongst a vast number of potential economic and financial measures, we chose the following key measures of enterprise-level performance:

- profitability measures (Hill et al. 1992; Goerzen and Beamish 2005; Goerzen 2007): Return on equity (ROE) and Return on sales (ROS);

- financial situation indicators: debt/equity ratio (Cantele and Vernizzi 2015) and liquidity ratio;

- a measure of debt sustainability (Ebitda/Interest) was also considered.

The economic and managerial literature substantially agrees on the presence of positive economic returns from networked interactions. It argues that isolated firms systematically show worse performance (Intesa Sanpaolo - Mediocredito Italiano 2014; Ricciardi and Ingarozza 2018) in comparison to firms that interact with one another. Taking into account the main types of Italian network contracts, we expected to verify - as suggested by the international literature (Williamson 1975; Storper and Harrison 1991; Oxley 1999; Cafaggi 2011; Fjeldstad et al. 2012; Ferraro et al. 2015) - that business networks equipped with legal personality are more effectively governed, work better, and thus allow partner firms to achieve better performance and survival over time than firms participating in "light" business networks. 


\section{Research methodology}

\section{Sample and data collection}

We conducted the analysis in two steps, testing the research questions through a mixed qualitative and quantitative approach.

To answer the first research question [RQ.1], we took a multi-method approach based on the following micro-phases (qualitative survey). This process was undertaken from July to December 2018. In the first micro-phase, the southern Italy network contracts were identified. The official list of network contracts, registered on 3 July 2017 and provided by the Italian Business Register, was considered in detail. The Italian Business Register is a public register of company data governed by the Italian Chambers of Commerce, which are functionally independent public bodies that perform functions of general interest for the business system. This list included (as of 3 July 2017) 3601 LCNs and 521 HCNs. From that list, we identified all network contracts established from 2011 to 2015 that mainly involved firms in the southern Italian regions (Abruzzo, Molise, Campania, Apulia, Basilicata, Calabria, Sicily, and Sardinia). Based on these parameters, 675 LCNs and 94 HCNs in southern Italy were selected (see Fig. 1).

The decision to consider only business networks established from 2011 to 2015 was due to the subsequent objective of verifying the economic-financial performance of the participating firms for at least two years after the date of establishment of the network - that is, through 2017 at the latest (at the time of data collection, the most recent available data were from 2017).

From the $675 \mathrm{LCNs}$ and the $94 \mathrm{HCNs}$ previously selected, we proceeded to identify which networks were in fact operating. For each network, the following aspects were investigated (second micro-phase): the existence of a dedicated website and its most recent update; its presence on social media; the presence of at least one direct telephone number of the network on its website; and the web availability of news and recent information on the activities of the network. These aspects were investigated on the assumption that an operational network must communicate its existence to its stakeholders and member firms and maintain up-to-date communication through websites, social media, and news media (Ricciardi et al. 2018).

The application of these criteria to the initial list led to the identification of 101 network contracts that can be classified as active/operational. Of these, 75 are light networks and 26 are heavy networks.

In the second micro-phase of the research, a semi-structured questionnaire was developed according to the literature on the topic. The questionnaire was then submitted (and subsequently discussed via telephone interviews) to a referent of each operating business network (third micro-phase). This phase aimed to both contribute to a better conceptualization of the underlying principles of the network contract and to enrich the existing literature on this topic, allowing us to answer the second research question [RQ.2].

The questionnaire was prepared by the authors and was divided into two sections. The first section aimed to acquire information that was useful for measuring the relationship capital generated by the network agreements. This included the number, size, and business sector of the partner firms; the history, purpose, and strategic objectives of the network; the nature (vertical, horizontal, mixed), location, and geographical span of the network; the year of establishment and the origins of collaboration 


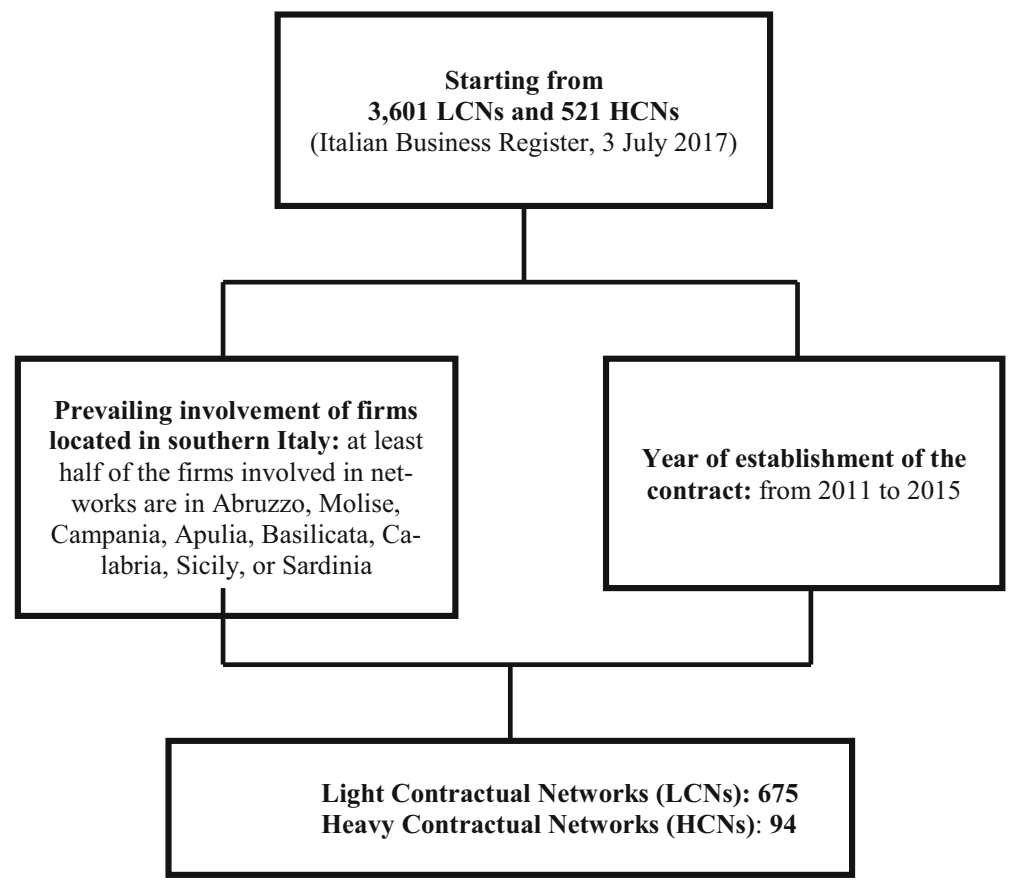

Fig. 1 Business Network-Sample selection process. Source: Our Elaboration

among the firms; and the network's system of governance. The second section was structured to detect and subsequently measure the effectiveness of the network contracts - or their influence on the growth and profitability of the firms involved as well as the perceptions of the interviewees. This section focused on the degree of trust and coordination among the network partners, the realization of the planned object and activities of the network, the existence of a common fund that could actually be used to make joint investments, the realization of common investments in product and/or process innovations, the network's performance level, and the economic and financial convenience of the aggregate companies to participate therein.

In the next stage (field) of research, the questionnaire was administered through telephone interviews with representatives of each network (leading firms, network managers, and entrepreneurs who manage the SMEs involved in the network agreements). In this phase, we contacted a representative for each of the 110 business networks found to be active/operative in first phase, and we invited them to answer the questionnaire. Only 41 interviews (equal to a $40.6 \%$ response rate) were successful. Of these, 16 represented HCNs (out of 26 active networks) and 25 (out of 75) represented LCNs. The telephone interviews were conducted between July and December 2018. All interview content was stored in a dedicated database (Boyatzis 1998).

From a quantitative point of view, this research aimed to answer research question [RQ. 3]. For this purpose, a quantitative analysis was performed on a sample of firms selected from those belonging to the $75 \mathrm{LCNs}$ and the $26 \mathrm{HCNs}$.

Out of a total of 739 firms belonging to the LCNs and 218 firms involved in the HCNs, only the limited firms were selected. These included 260 firms involved in the 75 LCNs (35.18\%) and 113 firms from the 26 HCNs $(51.83 \%)$. 
Subsequently, 23 firms (15 involved in the HCNs and 8 involved in the LCNs) were excluded because they were in default, in bankruptcy, or going out of business at the time of the accounting data extraction (November 2018). Therefore, the analysis was conducted on a final sample of 245 firms involved in the LCNs and 105 firms involved in the HCNs, for a total of 350 firms (see Fig. 2).

For all selected firms, we used the tax code as a firm identifier. The accounting data useful for the elaboration of the performance indicators used in the analysis were extracted for the period from 2010 to 2017 from the AIDA dataset. The AIDA contains comprehensive information on firms in Italy, with up to ten years of history provided by Bureau van Dijk, a Moody's Analytics company (at https://aida.bvdinfo.com). In the AIDA database, the financial data of firms classified as individual enterprises or associations of persons (i.e., simple/general/limited partnerships) are not covered; thus, we performed the analysis only on limited firms. Additional information used to create the control variables was collected and included firm size, firm age, and business sector.

\section{Variables used in the quantitative analysis}

Five measures of performance at the firm level were used as dependent variables, calculated for all years of the observation period. We analysed profitability using the Return on sales indicator (ROS, Ebit margin over Revenues) and the Return on equity (net income/equity). These measures of performance are accepted in the literature and used in the empirical studies on networking (Cisi et al. 2018; Hill et al. 1992; Goerzen and Beamish 2005; Goerzen 2007). As capital structure and liquidity indicators, Liquidity ratio ([total current assets - inventories]/ short term debt) and Leverage ratio (financial debts/equity) were considered (Gulati 1995; Beamish and Lupton 2009; Franco 2011; Kawai 2012; Cantele and Vernizzi 2015). Finally, a measure of debt sustainability (Ebitda/Interest) was used, to check whether participation in the network affected the creditworthiness of the credit applicants.

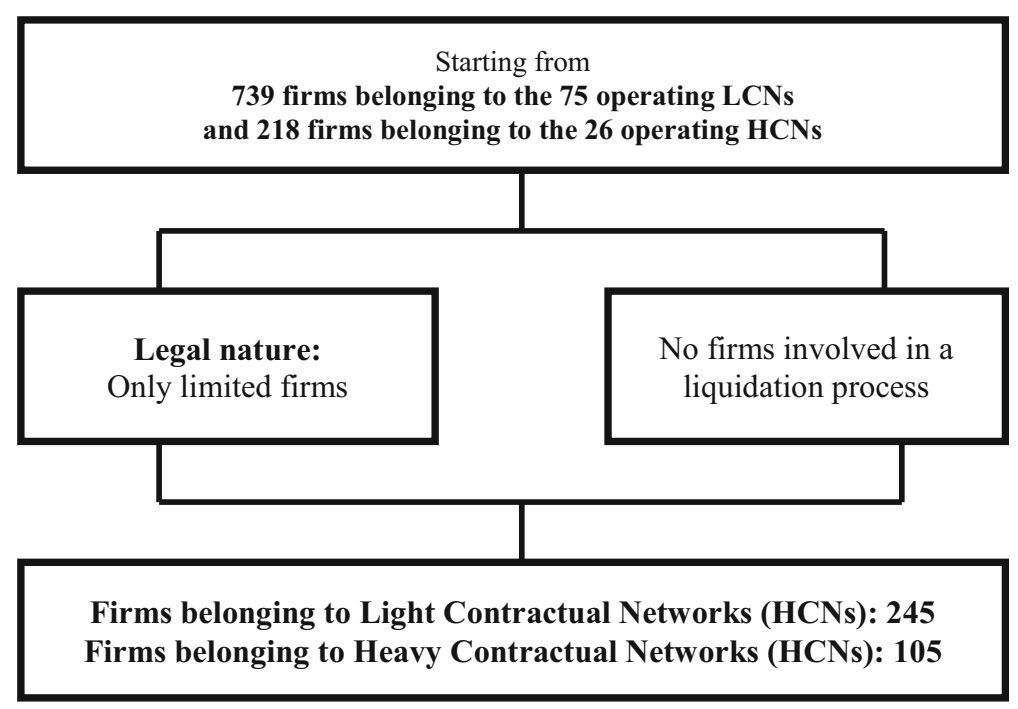

Fig. 2 Selection process of the sample of firms. Source: Our Elaboration 
The predictor variable is the type of network ( $\mathrm{LCN}$ or $\mathrm{HCN}$ ) in which the firm is involved. Two dummy variables were used rather than a single, simple dummy variable identifying the type of contract. This approach aimed to verify whether participation in a network (LCN or $\mathrm{HCN}$ ) was relevant for performance indicators with respect to the period preceding the establishment of the contract:

- Dummy_HCN ${ }_{\mathrm{it}}$ : 1 if the firm is involved in an $\mathrm{HCN}$ and 0 if the firm is not involved in an $\mathrm{HCN}$;

- Dummy_LCN ${ }_{\text {it: }} 1$ if the firm is involved in an LCN and 0 if the firm is not involved in an LCN.

Thus, different combinations of the two dummy variables identify three conditions at the firm level:

- the firm is not involved in a network: Dummy_HCN $\mathrm{H}_{\mathrm{it}}$ equal to 0 and Dummy_LCN $\mathrm{it}_{\mathrm{it}}$ equal to 0 . This situation occurs in the years preceding the signing of the contract by the firm;

- the firm is involved in an HCN: Dummy_HCN ${ }_{\text {it }}$ equal to 1 and Dummy_LCN $\mathrm{N}_{\text {it }}$ equal to 0 . This situation occurs starting from the year in which the firm signed a heavy network contract;

- the firm is involved in an LCN: Dummy_HCN ${ }_{\text {it }}$ equal to 0 and Dummy_LCN $\mathrm{L}_{\text {it }}$ equal to 1 . This situation occurs starting from the year in which the firm signed a light network contract.

Finally, according the related literature (Jiang et al. 2018), we included three often-used variables as control variables: firm age, firm size, and whether the firm was in the hightech sector. Firm age was measured by the logarithm of the number of years since the firm began. Firm size was measured by the logarithm of the revenue. "High-tech" was measured by a dummy variable: 1 (high-tech firms) and 0 (others). ${ }^{6}$

This data collection allowed for the creation of a panel dataset in which the behaviour of firms was observed across time and on which the analysis was performed.

\footnotetext{
${ }^{6}$ We have defined high-tech firms according to the classification of manufacturing industries and services provided by the statistical office of the European Union (Eurostat) and based on NACE Rev. 2 codes - 2-digit level (Statistical classification of economic activities in the European Community). Thus, we consider hightech firms to be those specialized in "Manufacture of basic pharmaceutical products and pharmaceutical preparations (Rev.2 code: 21); Manufacture of computer, electronic and optical products (26); Manufacture of chemicals and chemical products (20); Manufacture of electrical equipment; Manufacture of machinery and equipment n.e.c.; Manufacture of motor vehicles, trailers and semi-trailers; Manufacture of other transport equipment (27 to 30); Water transport; Air transport (50 to 51); Publishing activities; Motion picture, video and television programme production, sound recording and music publishing activities; Programming and broadcasting activities; Telecommunications; computer programming, consultancy and related activities; Information service activities (58 to 63); Financial and insurance activities (64 to 66); Legal and accounting activities; Activities of head offices, management consultancy activities; Architectural and engineering activities, technical testing and analysis; Scientific research and development; Advertising and market research; Other professional, scientific and technical activities; Veterinary activities (69 to 75); Employment activities (78); Security and investigation activities (80); Public administration and defence, compulsory social security; Education, Human health and social work activities; Arts, entertainment and recreation (84 to 93)".
} 


\section{Analysis and results}

\section{Qualitative analysis}

The first result of the qualitative analysis reveals a significant divergence between the number of network contracts surveyed in the database of the Confindustria-Retimpresa association and the number of network contracts resulting to be active. The networks surveyed are in fact clearly superior to those active and operating as networks. Only $13 \%$ (101) of all (769) network contracts signed by firms in southern Italy from 2011 to 2015 are actually operational. As shown in Fig. 3, amongst 94 official HCNs, only 26 are truly active. The largest sample of LCNs shows a similar trend: only 75 were active compared to a total of 675 .

As a final result, nearly $72 \%$ of $\mathrm{HCNs}$ are not operational; a similar trend was recorded for LCNs: almost $89 \%$ are not active.

We can conclude that in southern Italy, the phenomenon of business networks, at least as communicated officially, is outsized in comparison with the existing reality. This result suggests the need to verify the following in the next step of the research: (1) whether this phenomenon is limited to southern Italy or if it extends throughout the national territory, (2) why business networks do not work effectively or fail, (3) which factors and managerial skills are necessary to ensure an effective evolution of network contracts in future.

We remain convinced that business network contracts may help overcome the challenges stemming from the small size of the involved firms, especially those operating in the less developed areas of southern Italy. However, the results of the qualitative analysis (number of operational business networks and number of firms involved) suggest that the Italian model of business network contracts, as it has been implemented, has yet to encounter the anticipated success. We do not believe this failure is due to the existing regulatory framework. Instead, we think it is caused by problems of both the governance (especially, the lack of a network manager) and the operating conditions of business networks. These aspects are, in turn, determined by: (1) the presence of an efficient governance system; (2) the frequency of the contact (formal or informal) among the partners; and (3) the quality of the relationships (relational trust, consensus on goals).

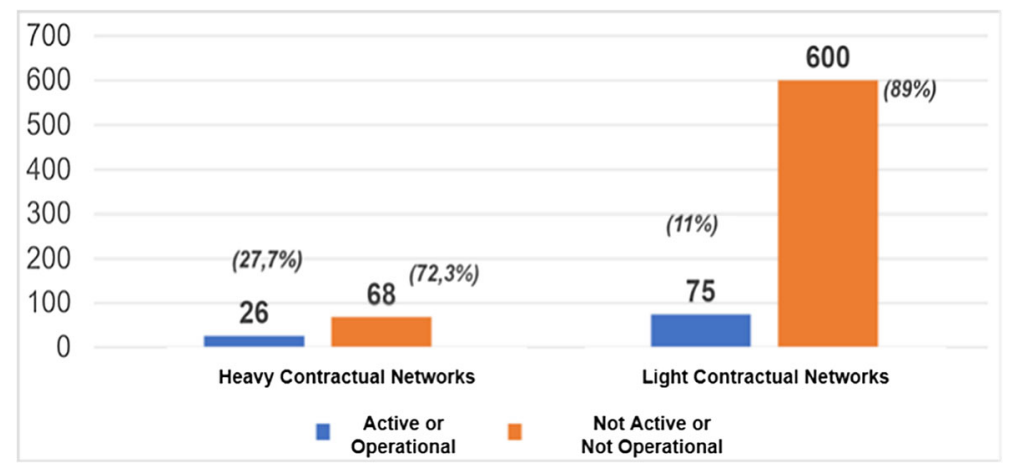

Fig. 3 Network contracts in Italy. Source: Our Elaboration 
These findings do not affect the relevance of the analysis. Rather, they indicate that the business network model is not the best way to encourage cooperation among SMEs, and it is not sufficiently attractive to smaller firms in the south of Italy. The latter may choose to remain small to avoid renouncing the benefits - even in tax and regulatory terms - that Italy offers to SMEs. However, through networks, SMEs should be able to reap greater benefits. They can develop strategies similar to those of medium-sized firms, benefit from tax benefits and other external incentives, and obtain a more favourable review of their bank ratings. Thus, the findings above suggest, above all, a development for the next phase of research, which must focus on a new (and likely more interesting) research question:

Why do these collaborative efforts fail to remain active? Why do networks fail to work effectively?

Another interesting finding concerns the low propensity to relationship and collaboration amongst southern Italy's firms in general (Calignano and Hassink 2016). Out of 5135 business network contracts signed in Italy over the past eight years, only 101 (equal to $13.0 \%$ ) of all registered business contracts in the south of Italy (769) are actually operating. Among these, 26 are network contracts with legal personality (out of a total of 94), and 75 are other types of network contract (out of a total of 675). These contracts involve only 957 firms: 218 firms adhere to the 26 active HCNs whilst 739 firms participate in the 75 active LCNs. The higher number of LCNs that are signed and are now acting-compared to HCNs - could be explained by the fact that small and medium entrepreneurs are firmly anchored in the "family logic" of business management. Thus, they may have little confidence in the idea of establishing long-lasting and binding relationships of reciprocal influence with other subjects (Ansoff 1987).

The general purpose of this research is to analyse the main characteristics of existing networks to determine whether the network models traditionally outlined by the literature in question are found in practice and are widespread among SMEs.

The interviews revealed a general consensus in terms of a positive evaluation of the network contract model and its interpretation as a strategic tool for the growth of small enterprises in Italy-especially for their internationalization and competitive advantage - from the perspective of creating value.

In most cases, there is a common fund dedicated to the activities of the network. This is supported (self-financed) by annual instalments paid by the member companies, by payment - on behalf of the subscribers - of $1 \%$ on the turnover of the network, and by any funding acquired through financing instruments promoted by public institutions to develop businesses.

In general, the success of the objectives of a network is conditioned by the following structural variables and critical relational variables: trust, size (number of participants), consensus on objectives, the nature of activities and competencies at the network level (Provan and Kesin 2008).

Based on the interviews, network management is mainly carried out collegially by the participants, with the possibility of delegating specific tasks to a participant (in $86 \%$ of cases) and/or outside the network. However, representatives of some business networks that are led by collective bodies face coordination problems. A network manager notes the following: 
"Our business network contract provides for a committee that should manage the network, but it is almost impossible to make its members sit around a table more than once a month. Any improvement is made thanks to the personal initiative of partners".

Furthermore, three models of network governance have been identified (Provan et al. 2007: 504; Lepistö et al. 2019: 263):

1. Horizontal governance model (shared governance) - Networks governed in a shared manner by the network partner firms that are, in fact, stable and reliable (according to the parties) due to the convergence of all partners on a common purpose and collectively, on an equal basis: they assume all decisions and manage network activities. They are responsible for managing internal network relations and operations as well as external relations with groups of financiers, governments and clients (Venkatraman and Lee 2004).

In the interviews conducted for our research, representatives of two networks (A, B) consider rules to be of little importance. They offer nearly the same perspective:

"We have some rules, but coordination is made day-by-day" (A).

"At the moment, we don't have that many rules and procedures; we still go on by solving everyday problems on the phone" (B).

2. Barycentric governance model (hub firm-governed) - Network governed by a lead organization or a leading body (management board) that assumes the functions of making fundamental decisions and management at the network level and ensures strategic control of the aggregate (Uzzi 1999; Inzerilli 1990; Lazerson 1995).

3. Intermediary governance model - Networks centrally governed by an administrative body (network committee or network manager) inside or outside the network that - by mandate or designation of partners - governs the network, coordinates its activities, proposes collective strategies, and manages the overall decision-making process.

In the network experience we observed in our research, the presence of a network manager, internal or external to the network, was also identified. This manager assists and supports the leading firm or the network president: (1) in the feasibility study and in the preparation and formalization of the network; and (2) in conducting, coordinating and managing the activities of the network during its formulation and maturation. In this regard, the president of a leading firm states the following:

"The governance of the business network is really complex, having to put together inevitable differences among the participants to better manage distances of various kinds (cognitive, cultural, managerial) among the partner firms. 
Hence, I would emphasise the usefulness of a neutral managerial figure, outside the network, namely a network manager with an high capacity of planning, coordination, and governance of the network."

The frequency of formal and more informal contacts among the representatives of the partner firms is 1 to 2 meetings per month; however, most contact occurs through emails and WhatsApp messages, in which individuals share best practices and opportunities. Relational trust encourages the parties to act correctly - that is, coherent with the contracted obligations - and it contributes to the creation of a climate of cooperation and co-responsibility that is necessary for the development of innovative and creative initiatives (Provan and Milward 1995).

Relational capital is a fundamental resource to achieve innovative capacity improvement. It has been verified that — when the formalization of a network occurs among enterprises that have already had an informal cooperative relationship - the degree of success and, therefore, the degree of network stability increases (Anand and Khanna 2000; Kale et al. 2002; Zollo et al. 2002; Sampson 2005; Heimeriks and Duysters 2007; Castaldi et al. 2015; Pastore et al. 2019).

In our interviews, the manager of two networks emphasizes the following:

"The contract, for us, is an opportunity to stabilize and normalize relationships that already existed among us."

Networks established among firms that have not previously collaborated are penalized and are more likely to fail due to the lack of mutual knowledge among the partners (Kale and Singh 1999; Zollo and Winter 2002; Draulans et al. 2003; Kale and Singh 2007; Brino et al. 2015).

\section{Quantitative analysis}

To empirically test the impact of the network and of the type of network (HCN or LCN) on firm performance, the following regression model was considered:

$$
Y_{i t}=\beta_{0}+\beta_{1} H C N_{i t}+\beta_{2} L C N_{i t}+\beta_{3} Z_{i t}+u_{i t}+\varepsilon_{i t}
$$

where firms $i$ (1 to 350) are measured on multiple years t (2010 to 2017). In the model: $\mathrm{Y}_{i t}$ represents the selected measure of performance (ROS, ROE, Liquidity ratio, Financial debts/equity, Ebitda/interest); $H C N_{i t}$ and $L C N_{i t}$ are the dummy variables that indicate, alternatively, the involvement of the firm in a network equipped with legal personality or in a network devoid of legal personality; $Z_{i t}$ is a vector of control variables able to explain performance: firm age, firm size, and whether the firm is in the high-tech sector; $u_{i t}$ is the between-firms error and $\varepsilon_{i t}$ is the within-firms error.

Analyses of longitudinal data can employ a variety of different methods based on fixed or random effects. In this study, a random model was chosen as suggested in the literature (Bell et al. 2019). 
The empirical strategy is based on the estimation of Eq. (1) for the whole sample. The main aspect of interest is the coefficient for the dummy variables $\mathrm{HCN}_{\mathrm{it}}$ and $\mathrm{LCN}_{\mathrm{it}}$. This aspect allowed us to explain the linkage between performance and network type as well as to compare firm performance in the pre-network period (before the firm signs the contract) versus the post-network period (after the firm signs the contract).

All the estimates take into account the panel structure of the database. The significance of the variables is tested using the Wald chi-square.

The correlations, means, and standard deviations are calculated as shown in Table 1. It emerges that the $\mathrm{HCN}$ variable is positively associated with the majority of performance measures.

The results in Table 2 suggest that there is a network effect and that participating in HCNs has a significantly positive effect on firm performance.

For profitability, significant results were found with regard to both ROS and ROE. For southern Italian firms, becoming a partner within an HCN implies the achievement of better returns on sales and equity. To provide more detail, ROE improves in the case of a firm involved in an $\mathrm{HCN}(\beta>0)$, and this improvement is statistically significant $(p<0.01)$. The establishment of an $\operatorname{LCN}(\beta>0)$ also has a positive effect, albeit lower $(p=0.101)$, on ROE. The variables of firm size and sector of specialization highlight a positive (and statistically significant) effect on ROE. Meanwhile, a negative impact comes from the variable of firm age. A positive impact on ROE is found when the size of the firm increases and in the case of high-tech manufacturing or services firms. Younger firms have better ROE; this result goes against expectations. However, some empirical studies show that older firms have a lower profitability index (Loderer and

Table 1 Descriptive statistics and correlation matrix

\begin{tabular}{|c|c|c|c|c|c|c|c|c|c|c|}
\hline Variables & 1 & 2 & 3 & 4 & 5 & 6 & 7 & 8 & 9 & 10 \\
\hline 1. ROS & 1.000 & & & & & & & & & \\
\hline 2. $\mathrm{ROE}$ & 0.444 & 1.000 & & & & & & & & \\
\hline 3. Liquidity ratio & 0.192 & 0.084 & 1.000 & & & & & & & \\
\hline $\begin{array}{l}\text { 4. Financial } \\
\text { debt/equity }\end{array}$ & -0.025 & -0.054 & -0.116 & 1.000 & & & & & & \\
\hline 5. Ebitda/interest & 0.232 & 0.133 & 0.198 & -0.137 & 1.000 & & & & & \\
\hline $\begin{array}{l}\text { 6. Heavy } \\
\text { Contractual } \\
\text { Network-HCN }\end{array}$ & 0.074 & 0.121 & -0.043 & 0.026 & 0.004 & 1.000 & & & & \\
\hline $\begin{array}{l}\text { 7. Light } \\
\text { Contractual } \\
\text { Network-LCN }\end{array}$ & -0.002 & -0.012 & 0.081 & -0.026 & 0.006 & -0.256 & 1.000 & & & \\
\hline 8. Firm age & 0.081 & -0.164 & 0.035 & 0.020 & -0.152 & 0.139 & -0.030 & 1.000 & & \\
\hline 9. Firm size ${ }^{a}$ & 0.007 & 0.015 & -0.098 & -0.020 & -0.074 & 0.357 & 0.113 & 0.357 & 1.000 & \\
\hline 10. High-tech & 0.072 & 0.065 & 0.192 & -0.026 & 0.102 & -0.010 & -0.032 & -0.042 & -0.379 & 1.000 \\
\hline Mean & 3.517 & 5.776 & 1.333 & 2.416 & 27.566 & 0.129 & 0.324 & 1.312 & 5.959 & 0.351 \\
\hline S.D. & 9.108 & 26.85 & 1.157 & 8.482 & 57.336 & 0.336 & 0.468 & 0.392 & 0.733 & 0.478 \\
\hline
\end{tabular}

${ }^{\text {a Log-transformed }}$ 
Table 2 Random effects regression model

\begin{tabular}{|c|c|c|c|c|c|}
\hline & ROS & ROE & Liquidity ratio & Financial debt/equity & Ebitda/interest \\
\hline Variables & $\begin{array}{l}\beta \\
\text { (S.E.) }\end{array}$ & $\begin{array}{l}\beta \\
\text { (S.E.) }\end{array}$ & $\begin{array}{l}\beta \\
\text { (S.E.) }\end{array}$ & $\begin{array}{l}\beta \\
\text { (S.E.) }\end{array}$ & $\begin{array}{l}\beta \\
\text { (S.E.) }\end{array}$ \\
\hline Heavy Contractual Network & $\begin{array}{l}1.039 * \\
(0.542)\end{array}$ & $\begin{array}{l}5.736^{* * * *} \\
(1.649)\end{array}$ & $\begin{array}{l}0.093^{*} \\
(0.054)\end{array}$ & $\begin{array}{l}-0.499 \\
(0.556)\end{array}$ & $\begin{array}{l}8.297 * * \\
(3.502)\end{array}$ \\
\hline Light Contractual Network & $\begin{array}{l}0.218 \\
(0.370)\end{array}$ & $\begin{array}{l}1.867 \\
(1.139)\end{array}$ & $\begin{array}{l}0.123 * * * \\
(0.037)\end{array}$ & $\begin{array}{l}-0.086 \\
(0.381)\end{array}$ & $\begin{array}{l}3.211 \\
(2.433)\end{array}$ \\
\hline Firm age & $\begin{array}{l}-1.163 \\
(0.815)\end{array}$ & $\begin{array}{l}-17.053 * * * \\
(2.342)\end{array}$ & $\begin{array}{l}0.132 \\
(0.094)\end{array}$ & $\begin{array}{l}1.008 \\
(0.766)\end{array}$ & $\begin{array}{l}-19.604 * * * \\
(5.69)\end{array}$ \\
\hline Firm size & $\begin{array}{l}3.405^{* * * *} \\
(0.528)\end{array}$ & $\begin{array}{l}11.014 * * * \\
(1.443)\end{array}$ & $\begin{array}{l}-0.104^{*} \\
(0.056)\end{array}$ & $\begin{array}{l}-1.899 * * * \\
(0.478)\end{array}$ & $\begin{array}{l}0.770 \\
(3.564)\end{array}$ \\
\hline High-tech & $\begin{array}{l}1.586^{*} \\
(0.823)\end{array}$ & $\begin{array}{l}5.121 * * \\
(2.328)\end{array}$ & $\begin{array}{l}0.463 * * * \\
(0.108)\end{array}$ & $\begin{array}{l}-1.329 * \\
(0.769)\end{array}$ & $\begin{array}{l}13.82 * * \\
(5.769)\end{array}$ \\
\hline Constant & $\begin{array}{l}-16.305 \\
(3.112)\end{array}$ & $\begin{array}{l}-43.933 \\
(8.562)\end{array}$ & $\begin{array}{l}1.582 \\
(0.335)\end{array}$ & $\begin{array}{l}13.202 \\
(2.821)\end{array}$ & $\begin{array}{l}40.070 * \\
(21.167)\end{array}$ \\
\hline Observation & 2366 & 2336 & 2421 & 2063 & 2078 \\
\hline Firms & 344 & 346 & 348 & 339 & 337 \\
\hline Wald Chi-square & $46.55^{* * * *}$ & $92.57 * * *$ & $50.45 * * *$ & $16.66^{* * * *}$ & $21.89 * * *$ \\
\hline
\end{tabular}

$* p<0.1$

$* * p<0.05$

$* * * p<0.01$

Waelchli 2010; Majumdar 1997; Akben-Selcuk 2016), which would seem to indicate a decline in their capacity to compete.

The firms involved in a network with legal personality show better performance in terms of net operating profitability (ROS): the HCN variable is statistically significant $(p<0.1)$ and positive $(\beta>0)$. The better performance - in terms of net operating profitability - of firms taking part in an HCN could be underpinned by more efficient cost structures and/or better pricing policies. This would allow the firms to benefit from stronger competitive positioning compared to small stand-alone firms. Firm size and high-tech sector affiliation also have a positive effect on performance.

The ability of the firm to fulfil its obligations, both financial and commercial, is positively influenced by the variables $\operatorname{HCN}(\beta>0, p<0.1)$ and $\operatorname{LCN}(\beta>0, p<0.01)$.

The sustainability of debt also improves; this is certainly due to the growth of the Ebitda. However, such improvement could also be the result of a reduction in interest rates applied by banks that recognise a lower risk linked with firms organized in HCNs.

The leverage indicator (Financial debt/equity) is not influenced by networking. Firm size and firm specialization (high-tech versus non-high-tech) determine a decrease in leverage, positively affecting the financial risk of the firm.

Firms that participate in active heavy contractual networks increase their profitability as well as improve their financial situation and debt sustainability. The analysis shows better results in these areas for firms participating in heavy contractual networks than for firms that participate in light contractual networks. This finding supports the idea that firms participating in HCNs achieve better performance than those involved in 
LCNs (RQ3). Our regression analysis seems to confirm - as claimed by the international literature (Williamson 1975; Fjeldstad et al. 2012; Ricciardi et al. 2014) - that business networks with legal personality are more effectively governed and thus function better, allowing partners to improve their economic performance.

Therefore, a network effect exists. Such effect appears to be associated with the operational conditions of the network: the presence of a (successful) governance system, the frequency of contact (formal or informal) among the partners, and the quality and stability of the relationships, specifically, strong relational capital.

\section{Conclusions. Limits, future research, implications}

This paper contributes to the debate on both the business network phenomenon and on the relationship between firm performance and network type (LCNs and HCNs). It does so by investigating, on the one hand, how many business networks are in fact operational in the south of Italy. By running a regression analysis, on the other hand, the paper provides evidence on how a southern Italian firm's membership in formal business networks affects many of its performance measures.

To the best of our knowledge, a comprehensive study has not previously been conducted on this topic in the Italian context. Thus, this is likely to be the first investigation into the effects of business networks on the performance of networked firms in the south of Italy.

This paper also contributes to the overall literature on business networks in several ways. First, it adopts a clear and formal definition of a business network based on Italy's 2009 law introducing the specific business agreement referred to as a "business network contract" (contratto di rete).

Second - and to the best of our knowledge for the first time - the paper investigates the importance of the business network contract phenomenon in the south of Italy. That is, it studies the phenomenon within a particular environmental context—one that is still characterised by numerous critical challenges that create significant disincentives to the competitiveness of both the firms and the territory. These include a lack of resources, infrastructure, and services for firms as well as a relatively low presence of social capital. However, this very less-than-favourable environmental could stimulate southern Italian firms to join networks and thereby avoid isolation. In fact, networking could help smaller firms to achieve critical mass in terms of size scale, resources and the availability of know-how, information, and experience. As such, networks can help them overcome the typical problems faced by firms in less developed areas.

Our empirical evidence seems to support the idea that networks could be beneficial for firms operating in environments that are characterised by intrinsic weaknesses in terms of supporting SMEs to compete, to survive, and to thrive. By stimulating the sharing of resources (as well as interactions and/or information exchanges), networking can be a win-win opportunity for Italian SMEs, particularly for those operating in the southern regions.

Another important contribution of this paper concerns the qualitative research. Only 13\% (101) of all (769) network contracts signed by firms in southern Italy from 2011 to 2015 are in fact operational. Thus, it seems that the business network phenomenon, at least in terms of how it is officially communicated, is outsized compared to the existing 
reality. This result suggests the importance of verifying the following in the next phase of research: (a) whether this phenomenon is limited to southern Italy or if it extends throughout the national territory, (b) why network contracts fail, (c) which managerial skills are necessary to ensure an effective evolution of network contracts in the future.

Moreover, the low number of firms that have signed business network contracts to date-despite a generally positive evaluation of the network contract model as a strategic tool to improve the growth and performance of Italy's SMEs - suggests a low propensity towards relationships and collaboration among many firms (linked also to a lack of strategic thinking). This may be exacerbated by the current business network model, as set forth by Italian law, which may not be sufficiently attractive to encourage cooperation among SMEs.

However, we are convinced that business network contracts could help SMEs overcome the difficulties stemming from their size. This positive network effect (if it exists) is not determined by an existing regulatory framework or by the type of network contract. Rather, this network effect can depend on an effective self-governance system (especially, the presence of a network manager) and operating conditions of the business networks (the frequency and quality of relationships, relational trust, and consensus on goals). This study's regression analysis to investigate the performance of firms that have signed business network contracts was somewhat limited due to the sample size of the analysed firms (only firms from southern Italy) and the short analysis period (2010-2017). However, the study showed positive and growing results in the case of both LCNs and HCNs in terms of profitability and financial position. The firms participating in the HCNs performed significantly better than the firms in the LCNs. Specifically, the former achieved better performance in:

(1) ROS index, providing evidence of firms' operational efficiency: firms taking part in a network with legal personality could be characterized by a more efficient cost structure and/or better pricing policies, benefiting from a stronger competitive positioning compared with small, stand-alone firms;

(2) ROE index: this factor could improve the ability of firms to attract investors, including professionals, to finance network projects;

(3) liquidity ratio: this factor has consequent beneficial effects on firms' solvency and capacity to repay debt;

(4) sustainability of debt: this result is achieved in part due to the growth of Ebitda. However, it could also be the result of reduced interest rates applied by banks that view firms organized into HCNs as lower-risk.

These results should not be surprising considering that the regression analysis was conducted on networks previously selected and labelled as active. These networks are characterized by operating models of network governance, frequent formal and informal contact among the partners, and strong relational capital. Our regression analysis confirms that business networks with legal personality are more effectively governed. Thus, they work better and allow partners to improve their economic performance.

The quality and reliability of this analysis could be improved by expanding it to further and broader empirical checks on a larger sample, extended to the whole national territory. A longer observation period would also allow for a temporal trend analysis. 
The business network contract may have interesting operational applications if further research will show that firms belonging to networks benefit from a network effect. If the network's capacity to offer firms dimensional growth, innovative capacity, and competitiveness - and if there are also credit risk assessment benefits (i.e., if banks are able to assess the relational system) - then cooperation and networks can be indicated as a development lever to help overcome the key size-related problems facing Italian SMEs.

\section{Limitations and future research}

This paper aims to provide a foundation for future research into governance for strategic business networks and the impact of said governance on firm performance, with particular reference to network contracts formalized under the Italian legal framework.

However, the paper presents several limitations:

First, as the study's results are based on qualitative and explorative research, it is difficult to extend them and the study's conclusions to all network contracts active in Italy.

Second, the analysis focused on business network contracts involving firms located in the south of Italy, which represents only a relatively small segment of the Italian socio-economic context.

Third, the sample period of 2011 to 2015 (relating to the signing of contracts) is relatively short, as is the span from 2010 to 2017 (relating to the analysed performance of the partner firms). The limited time frame is also due to the short lifespan, to date, of Italy's business network contract regulations. This is only the first phase of our research, which we aim to extend to the whole national territory of Italy over time to obtain a temporal analysis on the relevant trends.

These issues limit the generalization of our results.

Nevertheless, the above findings open additional scenarios and indicate some possible directions for further research, such as to:

- extend the analysis to a larger sample (the entire national territory) and over a longer observation period and to verify the success factors and/or the causes of failure of networks of firms within the same territory;

- identify and analyse successful case studies of business networks that have been capable of achieving high levels of competitiveness;

- develop a repertoire of best practices that are useful to the various network players and policy makers to promote, at a regional level, the ability of business networks to act not only as "reticular production chains" but also as real local innovation systems;

- investigate why most business network contracts remain inactive and/or do not work effectively.

An additional finding of the research shows that the success of network alliances is strongly influenced by the quality of network governance. The latter factor is based strictly on the quality and ability of the managers. We argue that the legal framework concerning business 
network contracts requires a necessary managerial, professional, and cultural improvementspecifically related to strategic planning, governance, and performance measurement and control processes in business networks. The main dimensions to be investigated on this front are: (1) the number, nature, and characteristics of the actors making up the network; (2) the overall network configuration; (3) the type and intensity of the relationships among these actors; (4) the key roles played by the actors; and (5) the critical success factors and network criticality that limit the capacity of these networks to effectively operate.

\section{Implications}

Despite its limits, this paper is intended to better inform network managers, practitioners, and policy makers about the "state of the art" of business network contracts signed in the south of Italy at this juncture, just over 10 years from their introduction. While there is a consensus on the potential benefits of network contracts, and the OECD (2014) considers the Italian network contract to be an example of good practice, it would be useful to improve some critical aspects related to the implementation of these contracts. Given the findings described above, more appropriate incentives should be provided to stimulate southern Italian firms to adhere to the more formalized and structured version - the business network contract with legal personality or heavy contractual network.

In this respect, as both scholars and entrepreneurs often argue, national and regional incentives for firms signing business network contracts are overly focused on innovation, tax credits, and other fiscal benefits. Many of these features are not necessary.

As one manager noted, "The tax credit does not interest us ... it is the ideas (that are) the necessary precondition for every action". Similarly, another manager said "We must have a clear vision and our own concept of teamwork, regardless of tax benefits".

Policy makers could effectively devote more effort and resources, in particular, to offering incentives that are designed to encourage firms' choosing HCNs over LCNs. These networks could be supported to succeed by emphasizing the vital roles of appropriate planning, programming, and control systems; more effective tools; and managerial figures, such as network managers, who are devoted to their direction, coordination, and governance.

The Italian business network contract may have interesting operational applications, since cooperation and networks are indicated as a developmental lever that can overcome the main problems related to the small size of Italian firms.

Acknowledgements The authors wish to thank the two anonymous reviewers for their careful reading of the manuscript and their valuable comments and suggestions, which have substantially contributed to the improvement of this final version of the paper.

The authors are also grateful for the insightful suggestions on an earlier version of this paper, received during its presentation at the 10th INEKA Conference in 2019 (University of Verona, Italy).

Warm thanks go to the editors, and particularly Mrs. Carla Martinez Climent, for her guidance and support through the review process.

\section{Compliance with ethical standards}

Conflict of interest The authors declare that they have no conflict of interest.

Open Access This article is licensed under a Creative Commons Attribution 4.0 International License, which permits use, sharing, adaptation, distribution and reproduction in any medium or format, as long as you give appropriate credit to the original author(s) and the source, provide a link to the Creative Commons licence, and 
indicate if changes were made. The images or other third party material in this article are included in the article's Creative Commons licence, unless indicated otherwise in a credit line to the material. If material is not included in the article's Creative Commons licence and your intended use is not permitted by statutory regulation or exceeds the permitted use, you will need to obtain permission directly from the copyright holder. To view a copy of this licence, visit http://creativecommons.org/licenses/by/4.0/.

\section{References}

Accetturo, A., Giunta, A., \& Rossi, S. (2011). Le imprese italiane tra crisi e nuova globalizzazione. Bank of Italy-Questioni di Economia e Finanza (Occasional papers), No. 86, January.

Agostino, D., \& Arnaboldi, M. (2015). How performance measurement systems support managerial actions in networks: Evidence from an Italian case study. Public Organization Review, 15(1), 117-137.

Agostino, M., Giunta, A., Nugent, J. B., Scalera, D., \& Trivieri, F. (2015). The importance of being a capable supplier: Italian industrial firms in global value chains. The International Small Business Journal, 33(7), $708-730$.

Ahmad, S. Z., \& Kitchen, P. J. (2008). International expansion strategies of Malaysian construction firms: Entry mode choice and motives for investment. Journal of Problems and Perspectives in Management, $6(3), 15-23$.

Akben-Selcuk, E. (2016). Does firm age affect profitability? Evidence from Turkey. International Journal of Economic Sciences, V(3), 1-9.

Alberti, F. (2012). Il contratto di rete: una rassegna. Studi Organizzativi, 2, 176-197.

Alter, C., \& Hage, J. (1993). Organizations working together. London: Sage Publications.

Altomonte, C., \& Ferri, G. (2012). Per lo sviluppo d'impresa: reti non gabbie. In F. Cafaggi, P. Iamiceli, \& G. D. Mosco (Eds.), Il Contratto di rete per la crescita delle imprese (pp. 15-28), Quaderni di Giurisprudenza commerciale. Milano: Giuffrè Editore.

Anand, B. N., \& Khanna, T. (2000). Do firms learn to create value? The case of alliances. Strategic Management Journal, 21, 295-315.

Ansoff, H. I. (1987). The emerging paradigm of strategic behavior. Strategic Management Journal, 8 (6), 501515.

Arrigo, T. (2013). Il contratto di rete. Profili giuridici. In A. Tunisini, G. Capuano, T. Arrigo, \& R. Bertani (Eds.), Contratto di rete. Lo strumento Made in Italy per integrare individualità e aggregazione (pp. 3554). Milano: Franco Angeli.

Aureli, S., Ciambotti, M. \& Del Baldo, M. (2011). Inter-organizational networks as a strategic response to current economic challenges. The Italian experience of the "network contract": Analysis of networks formation, goals and governance (pp. 1-28). Rent XXV proceedings, research in entrepreneurship and small business, 25th anniversary conference, entrepreneurial, business and society, Bodo, Norway, 16-18 November 2011.

Axelrod, R. (1984). The evolution of cooperation. New York: Harper Collins.

Baker, G. (1992). Incentive contracts and performance measurement. Journal of Political Economy, 100, 598614.

Baker, G. (2000). The use of performance measures in incentive contracting. American Economic Review, $100,415-420$.

Barney, J. (1991). Firm resources and sustained competitive advantage. Journal of Management, 17(1), 99120.

BarNir, A., \& Smith, K. A. (2002). Interfirm alliances in the small business: The role of social networks. Journal of Small Business Management, 40, 219-232.

Baron, R., \& Markman, G. (2003). Beyond social capital: The role of entrepreneurs' social competence in their financial success. Journal of Business Venturing, 18(1), 41-60.

Beamish, P. W., \& Lupton, N. C. (2009). Managing joint ventures. The Academy of Management Perspectives, 23(2), 75-94.

Bell, A., Fairbrother, M., \& Jones, K. (2019). Fixed and random effects models: Making an informed choice. Quality \& Quantity, 53, 1051-1074.

Bentivogli, C., Quintiliani, F., \& Sabbatini, D. (2013). Le reti di imprese. Banca d'Italia, Questioni di Economia e Finanza (Occasional papers), No.152, Febbraio. 
Bodnaruk, A., Massa, M., \& Simonov, A. (2013). Alliances and corporate governance. Journal of Financial Economics, 107(3), 671-693.

Boisot, M. H. (1998). Knowledge assets. New York: Oxford University Press.

Boyatzis, R. E. (1998). Transforming qualitative information: Thematic analysis and code development. New York: Sage.

Brand, M. J., Croonen, E. P. M., \& Leenders, R. T. A. J. (2018). Entrepreneurial networking: A blessing or a curse? Differential effects for low, medium and high performing franchisees. Small Business Economics, 50, 783-805.

Brandolini, A., \& Bugamelli, M. (Eds.) (2009). Rapporto sulle tendenze del sistema produttivo italiano. Bank of Italy-Questioni di Economia e Finanza (Occasional papers), No. 45, April.

Brass, D. J., Galaskiewicz, J., Greve, H. R., \& Tsai, W. (2004). Taking stock of networks and organizations: A multilevel perspective. Academy of Management Journal, 47, 795-817.

Brino, V., Grandinetti, R., \& Mattei, A. (2015). L'esperienza dei contratti di rete. Economia e Società Regionale, n. 33 (2), 5-10.

Budde, J. (2007). Performance measure congruity and the balanced scorecard. Journal of Accounting Research, 45, 515-539.

Bugamelli, M., Cipollone, P., \& Infante, L. (2000). L'internazionalizzazione delle imprese italiane negli anni '90. Rivista italiana degli economisti, 3(December), 349-386.

Bugamelli, M., Cannari, L., Lotti, F., \& Magri, S. (2012). Il gap innovativo del Sistema produttivo italiano: radici e possibili rimedi. Bank of Italy, Questioni di Economia e Finanza (Occasional papers), No.121, April.

Cafaggi, F. (2009). Il contratto di rete. Bologna: Il Mulino.

Cafaggi, F. (2011). Contractual networks, inter-firm cooperation and economic growth. Northampton: Edward Elgar Cheltenham UK.

Cai, J., \& Szeidl, A. (2018). Interfirm relationships and business performance. The Quarterly Journal of Economics, 133(3), 1229-1282.

Calignano, G., \& Hassink, R. (2016). Increasing innovativeness of SMEs in peripheral areas through international networks? The case of southern Italy. Region, 3(1), 25-42.

Cantele, S., \& Vernizzi, S. (2015). The Effect of network participation on firm performance: A Matched-pairs analysis. 8th Annual Conference of the EuroMed Academy of Business "Innovation, Entrepreneurship and Sustainable Value Chain in a Dynamic Environment”, Verona, September 16-18, 2015, Conference Readings Book Proceedings, 375-387.

Cantele, S., Vernizzi, S., \& Ricciardi, F. (2016). The emerging wave of agility-oriented business networks in Italy: A new strategy for facing global competition. World Review of Entrepreneurship, Management and Sustainable Development, 12(2/3), 270-284.

Cardoni, A. (2012). Business planning and management accounting in strategic networks: Theoretical development and empirical evidence from enterprises' network “agreements,". Management Control, 3, 91-116.

Carini, C., \& Muzzi, C. (2016). The Italian network contract: A "new" form of networking with "old" rules? Genesis, dynamics and challenges (pp. V-83-V-107). In L. Marchi, L. Anselmi, \& R. Lombardi (Eds.), Il governo aziendale tra tradizione e innovazione - Sezione VI "Strategie di sviluppo, risanamento e cooperazione”. Milano: Franco Angeli.

Castaldi, L., Turi, C., Mazzoni, C., \& Delli Paoli, A. (2015). Antecedents and constituents of alliance management capability: The role of valuable alliance experience and governance mechanisms for learning. Journal of Management and Governance, 19(4), 797-823.

Cefis, E., \& Marsili, O. (2005). A matter of life and death: Innovation and firm survival. Industrial and Corporate Change, 14(6), 1167-1192.

Child, J., \& Faulkner, D. (1998). Strategies of co-operation: Managing alliances, networks and joint ventures. Oxford: Oxford University Press.

Cisi, M., Devicienti, F., Manello, A., \& Vannoni, D. (2016). Network agreements and firms' economic performance: New empirical evidence from Italian SMEs (pp. V-65-V-82). In L. Marchi, L. Anselmi, \& R. Lombardi (Eds.), Il governo aziendale tra tradizione e innovazione - Sezione VI "Strategie di sviluppo, risanamento e cooperazione". Milano: Franco Angeli..

Cisi, M., Devicienti, F., Manello, A., \& Vannoni, D. (2018). The advantage of formalizing networks: New evidence from Italian SMEs. Small Business Economics, December, 1-18.

Collins, C., \& Clark, K. (2003). Strategic human resource practices, top management team social networks, and firm performance: The role of human resource practices in creating organizational competitive advantage. Academy of Management Journal, 46(6), 740-751. 
Das, T. K., \& Teng, B. (2000). A resource-based theory of strategic alliances. Journal of Management, 26(1), 31-61.

De Man, A. P., \& Roijakkers, N. (2009). Alliance governance: Balancing control and Trust in Dealing with risk. Long Range Planning, 42, 75-95.

Dooley, L., Kenny, B., \& Cronin, M. (2016). Interorganizational innovation across geographic and cognitive boundaries: Does firm size matter? R\&D Management, 46(S1), 227-243.

Draulans, J., deMan, A. P., \& Volberda, H. W. (2003). Building alliance capability: Management techniques for superior alliance performance. Long Range Planning, 36(2), 151-166.

Drewniak, R., \& Karaszewski, R. (2019). Diffusion of knowledge in strategic alliance: Empirical evidence. International Entrepreneurship and Management Journal. https://oi.org/10.1007/s11365-019-00589-2.

Dyer, J., \& Singh, H. (1998). The relational view: Cooperative strategy and sources of interorganizational competitive advantage. The Academy of Management Review, 23(4), 660-679.

Etzkowitz, H. (2008). The triple Helix: University-industry-government innovation in action. London: Routledge.

European Commission (2011). Review of the "Small business ACT" for Europe, Brussels 23.2.2011, COM (2011) 78 final. Communication from the Commission to the European Parliament, the Council, Economic and Social Committee and the Committee of the Regions http://eur-lex.europa.eu/.

European Commission (2012). Capacities. Part 2: Research for the benefit of SMEs. Belgium.

European Commission (2014). European Competitiveness Report: Helping firms grow. Commission staff working document SWD (2014) 277 final. Brussels: European Union.

European Commission (2017). Annual report on European SMEs 2016/2017 focus on self-employment SME performance review, November.

Eurostat (2014). Community Innovation Survey (CIS 2014) http://ec.europa.eu/eurostat/eurostat/data/database.

Eurostat. (2017). Eurostat regional yearbook (2017th ed.). Luxembourg: Publications Office of the European Union.

Fernhaber, S. A., \& Li, D. (2013). International exposure through network relationships: Implications for new venture internationalization. Journal of Business Venturing, 28(2), 316-334.

Ferraro, F., Etzion, D., \& Gehman, J. (2015). Tackling grand challenges pragmatically: Robust action revisited. Organization Studies, 36(3), 363-390.

Fjeldstad, O. D., Snow, C. C., Raymond, E. M., \& Lettl, C. (2012). The architecture of collaboration. Strategic Management Journal, 33(6), 734-750.

Fornoni, M., Arribas, I., \& Vila, J. E. (2011). Measurement of an individual entrepreneur's social capital: A multidimensional model. International Entrepreneurship and Management Journal, 7(4), 495-507.

Franco, M. (2011). Determining factors in the success of strategic alliances: An empirical study performed in Portuguese firms. European Journal of International Management, 5(6), 608-632.

Franco-Santos, M., Lucianetti, L., \& Bourne, M. (2012). Contemporary performance measurement systems: A review of their consequences and a framework for research. Management Accounting Research, 23(2), 79-119.

Fuentes, M. M. F., Arroyo, M. R., Bojica, A. M., \& Pérez, V. F. (2010). Prior knowledge and social networks in the exploitation of entrepreneurial opportunities. International Entrepreneurship and Management Journal, 6(4), 481-501.

Gardet, E., \& Fraiha, S. (2012). Coordination modes established by the hub firm of an innovation network: The case of an SME bearer. Journal of Small Business Management, 50(2), 216-238.

Geretto, E., \& Zanin, F. (2017). Aggregazione e reti di imprese. Teoria, metodi e strumenti per la strategia, la valutazione della performance e il rating assignment. Torino: Giappichelli Editore.

Giunta, A. (2014). Imprese italiane e catene globali del valore: che cosa sappiamo? ICE, L'Italia nell'economia internazionale. Rapporto ICE 2013-2014.

Goerzen, A. (2007). Alliance networks and firm performance: The impact of repeated partnerships. Strategic Management Journal, 2, 487-509.

Goerzen, A., \& Beamish, P. W. (2005). The effect of alliance network diversity on multinational enterprise performance. Strategic Management Journal, 26, 333-354.

Gulati, R. (1995). Social structure and alliance formation patterns: A longitudinal analysis. Administrative Science Quarterly, 40, 619-652.

Gulati, R., \& Higgins, M. (2003). Which ties matter when? The contingent effects of interorganizational partnerships on IPO success. Strategic Management Journal, 24(2), 127-144.

Gulati, R., Lawrence, P., \& Puranam, P. (2005). Adaptation in vertical relationships: Beyond incentive conflict. Strategic Management Journal, 26(12), 415-440.

Håkansson, H., \& Snehota, I. (1995). Developing relationships in business networks. Boston: Thompson Press. 
Håkansson, H., Ford, D., Gadde, L., Snehota, I., \& Waluszewski, A. (2009). Business in networks. Chichester: Wiley.

Hanna, V., \& Walsh, K. (2008). Inter-firm cooperation among small manufacturing firms. International Small Business Journal, 26(3), 299-321.

Heimeriks, K. H., \& Duysters, G. (2007). Alliance capability as a mediator between experience and Alliance performance: An empirical investigation into the Alliance capability development process. Journal of Management Studies, 44, 25-49.

Hill, C. W. L., Hitt, M. A., \& Hoskisson, R. E. (1992). Cooperative versus competitive structures in related and unrelated diversified firms. Organization Science, 3, 501-521.

Hoang, H., \& Antoncic, B. (2003). Network-based research in entrepreneurship: A critical review. Journal of Business Venturing, 18, 165-187.

Huggins, R. (2001). The skills economy and its development: Examples and lessons from a rural region. Policy Studies, 22(1).

Huxham, C., \& Vangen, S. (2005). Managing to collaborate: The theory and practice of collaborative advantage. New York: Routledge.

Intesa Sanpaolo - Mediocredito Italiano (2014). Il quinto Osservatorio sulle reti d'impresa, November.

Inzerilli, G. (1990). The Italian perspective: Flexible organization and social management. International Studies of Management and Organization, 20, 6-21.

Istat (2018). Annuario Statistico Italiano 2018, Capitolo 14-Imprese, Roma.

Jarillo, C. (1988). On strategic networks. Strategic Management Journal, 9(1), 31-41.

Jarillo, C. (1993). Strategic networks. Oxford: Butterworth-Heinemann.

Jenssen, J. I., \& Nybakk, E. (2013). Inter-organizational networks and innovation in small, knowledge intensive firms: A literature review. International Journal of Innovation Management, 17(02).

Jiang, X., Liu, H., Fey, C., \& Jiang, F. (2018). Entrepreneurial orientation, network resource acquisition, and firm performance: A network approach. Journal of Business Research, 87, 46-57.

Johnson, M., \& Lundberg, H. (2011). Network strategies for regional growth. New York: Palgrave MacMillan.

Kale, P., \& Singh, H. (1999). Building alliance capabilities: A knowledge-based approach. Chicago: Academy of Management Best Paper Proceedings.

Kale, P., \& Singh, H. (2007). Building firm capabilities through learning: The role of the alliance learning process in alliance capability and firm-level alliance success. Strategic Management Journal, 28(10), 981-1000.

Kale, P., Dyer, J. H., \& Singh, H. (2002). Alliance capability, stock market response, and long-term Alliance success: The role of the Alliance function. Strategic Management Journal, 23(8), 747-767.

Kawai, N. (2012). The influence of external network ties on organisational performance: Evidence from Japanese manufacturing subsidiaries in Europe. European Journal of International Management, 6(2), $221-242$.

Keung, C. C., \& Shen, L. Y. (2012). Measuring the networking performance for contractors in practicing construction management. Journal of Management in Engineering, 29(4), 400-406.

Kirby, D. A., \& Kaiser, S. (2005). SME Foreign Investment. International Entrepreneurship and Management Journal, 1, 83-104.

Landsperger, J., Spieth, P., \& Heidenreich, S. (2012). How network managers contribute to innovation network performance. International Journal of Innovation Management, 16(06), 1-21.

Laperche, B., \& Liu, Z. (2013). SMEs and knowledge-capital formation in innovation networks: A review of literature. Journal of Innovation and Entrepreneurship, 2(21), 1-16.

Laurell, H., Achtenhagen, L., \& Andersson, S. (2017). The changing role of network ties and critical capabilities in an international new venture's early development. International Entrepreneurship and Management Journal, 13, 113-140.

Lazerson, M. (1995). A new Phoenix? Modern putting-out in the Modena knitwear industry. Administrative Science Quarterly, 40, 34-59.

Lechner, C., \& Dowling, M. (2003). Firm networks: External relationships as sources for the growth and competitiveness of entrepreneurial firms. Entrepreneurship \& Regional Development: An International Journal, 15(1), 1-26.

Lechner, C., Dowling, M., \& Welpe, I. (2006). Firm networks and firm development: The role of the relational mix. Journal of Business Venturing, 21, 514-540.

Lee, C. W., Lee, K. M., \& Pennings, J. (2001). Internal capabilities, external networks, and performance: A study on technology-based ventures. Strategic Management Journal, Special issue on "Strategic entrepreneurship: Entrepreneurial strategies for wealth creation,", 22(6-7), 364-381. 
Lepistö, T., Mäkitalo-Keinonen, T., \& Valjakka, T. (2019). Opportunity recognition in a hub-governed network - Insights from garage services. International Entrepreneurship and Management Journal, 15, 257-280.

Li, H., Corral de Zubielqui, G., \& O’Connor, A. (2015). Entrepreneurial networking capacity of cluster firms: A social network perspective on how shared resources enhance firm performance. Small Business Economics, 45, 523-541.

Lin, F., \& Lin, Y. (2016). The effect of network relationship on the performance of SMEs. Journal of Business Research, 69, 1780-1784.

Linton, J. D., \& Solomon, G. (2017). Technology, innovation, entrepreneurship and the small business Technology and innovation in small business. Journal of Small Business Management, 55(2), 196-199.

Loderer, C.F., \& Waelchli, U. (2010). Firm age and performance. SSRN Working Paper; No. 1342248, DOI: https://doi.org/10.2139/ssrn.1342248.

Löfsten, H. (2016). New technology-based firms and their survival: The importance of business networks, and entrepreneurial business behaviour and competition. Local Economy, 31(3), 393-409.

Lu, J. W., \& Beamish, P. W. (2001). The internationalization abd performance of SMEs. Strategic Management Journal, 22, 565-586.

Majumdar, S. K. (1997). The impact of size and age on firm-level performance: Some evidence from India. Review of Industrial Organization, 12(2), 231-241.

Mancini, D., \& Piscitelli, G. (2018). Performance measurement systems in business networks: A literature review. International Journal Business Performance Management, 19(1), 87-104.

Mazzola, E., Perrone, G., \& Kamuriwo, D. (2016). The interaction between inter-firm and interlocking directorate networks on firm's new product development outcomes. Journal of Business Research, 69, 672-682.

McEvily, S., \& Chakravarthy, B. S. (2002). The persistence of knowledge-based advantage: An empirical test for product performance and technological knowledge. Strategic Management Journal, 23(4), 285-305.

Mediobanca-Unioncamere (2017). Italian medium-sized enterprises - Annual survey of medium-sized Italian businesses, November.

Meiseberg, B., \& Ehrmann, T. (2013). Tendency to network of small and medium-sized enterprises: Combining organizational economics and resource-based perspectives. Managerial and Decision Economics, 34(3-5), 283-300.

Nelson, R. R., \& Winter, S. G. (1982). An evolutionary theory of economic change. Cambridge: Belknap Press of Harvard University Press.

Ng, W., \& Rieple, A. (2014). Guest Editors' introduction to special issue on "the role of networks in entrepreneurial performance: New answers to old questions? International Entrepreneurship and Management Journal, 10, 447-455.

Nickerson, J. A., \& Zenger, T. R. (2004). A knowledge-based theory of the firm-The problem-solving perspective. Organization Science, 15(6), 617-632.

Nonaka, I. (1994). A dynamic theory of organizational knowledge creation. Organization Science, 5(1), 14 37.

OECD. (2014). Italy: Key Issues and Policies. OECD Studies on SMEs and Entrepreneurship. Paris: OECD Publishing.

Oliver, A., \& Ebers, M. (1998). Networking network studies: An analysis of conceptual configurations in the study of inter-organizational relationships. Organization Studies, 19(4), 549-583.

Oxley, J. E. (1999). Institutional environment and the mechanisms of governance: The impact of intellectual property protection on the structure of inter-firm alliances. Journal of Economic Behavior and Organization, 38(3), 283-309.

Parker, S. C. (2008). The economics of entrepreneurship. Cambridge: Cambridge University Press.

Pastore, P. (2009). Modelli e strutture di governance nei distretti industriali e nelle reti di imprese (pp. 97-149). In S. Tommaso (Ed.), Distretti e reti di imprese. Evoluzione organizzativa, finanza innovativa, valutazione mediante rating. Milano: Franco Angeli.

Pastore, P., Ricciardi, A., \& Tommaso, S. (2019). The Italian "network contract": Strategic cooperation tool for competitiveness of SMEs in the agribusiness sector (pp. 1288-1307). In G. Schiuma, P. Demartini, \& M. R. Yan (Eds). Knowledge ecosystems and growth, conference proceedings 14th international forum on knowledge asset dynamics (IFKAD 2019), Matera, Italy 5-7 June 2019,

Peteraf, M. A. (1993). The cornerstones of competitive advantage: A resource-based view. Strategic Management Journal, 14(3), 179-191.

Powell, W. (1990). Neither market nor hierarchy: Network forms of organization. Research in Organizational Behavior, 12, 295-336. 
Prahalad, C. K. (1993). The role of core competencies in the corporation. Research Technology Management, $36(6), 40-47$.

Provan, K. G., \& Kesin, P. (2008). Modes of network governance: Structure, management, and effectiveness. Journal of Public Administration Research and Theory, 18(2), 229-252.

Provan, K. G., \& Milward, H. B. (1995). A preliminary theory of network effectiveness: A comparative study of four community mental health systems. Administrative Science Quarterly, 40, 1-33.

Provan, K. G., Fish, A., \& Sydow, J. (2007). Interorganizational networks at the network level: A review of the empirical literature on whole networks. Journal of Management, 33(3), 479-516.

Ramadani, V., Abazi-Alili, H., Dana, L. P., Rexhepi, G., \& Ibraimi, S. (2017). The impact of knowledge spillovers and innovation on firm-performance: Findings from the Balkans countries. International Entrepreneurship and Management Journal, 13(1), 299-325.

Ricciardi, A. (2003). Le reti di imprese. Vantaggi competitivi e pianificazione strategica. Milano: Franco Angeli.

Ricciardi, A. (2010). Strategie di cooperazione tra aziende e mitigazione del rischio operativo: i vantaggi competitivi delle reti di imprese (pp. 1415-1424). In G. Airoldi, G. Brunetti, G. Corbetta, \& G. Invernizzi (Eds.), Economia Aziendale and Management: scritti in onore di Vittorio Coda. Milano: Egea.

Ricciardi, A. (2014). Strategie di collaborazione tra imprese: le reti (pp. 23-72). In G. Fabbrini \& A. Montrone (Eds.), Economia Aziendale. Ricerche e profili evolutivi. Milano: Franco Angeli.

Ricciardi, A. (2016). Crediti deteriorati e piccola dimensione delle imprese: l'opportunità delle reti. Rassegna Economica, 1, 41-73.

Ricciardi, A., \& Ingarozza, M. F. (2018). Organizzarsi in rete per migliorare il rating e ridurre il costo dei finanziamenti. Amministrazione \& Finanza, 33(3), 79-90.

Ricciardi, A., Cardoni, A., \& Tiacci, L. (2014). Strategic context, organizational features and network performances: A survey on collaborative networked organizations of Italian SMEs (pp.534-545). In L. M. Amarinha-Matos, \& H. Afsarmanesh (Eds.). Collaborative systems for smart networked environments, IFIP Advances in Information and Communication Technology, Springer Berlin Heidelberg, Vol. 434.

Ricciardi, F., Zardini, A., \& Rossignoli, C. (2018). Business network commons and their fragilities: Emerging configurations of local organizational fields. Journal of Business Research, 89, 328-335.

Rosenfeld, S. A. (1996). Does cooperation enhance competitiveness? Assessing the impacts of inter-firm cooperation. Research Policy, 25(2), 247-263.

Rullani, E. (2011). La conoscenza e le reti: gli orizzonti competitivi del caso italiano e una riflessione metodologica sull'economia di impresa. Sinergie, 61(62), 147-187.

Sampson, R. C. (2005). Experience effects and collaborative returns in R\&D alliances. Strategic Management Journal, 26(11), 1009-1031.

Santarelli, E., \& Vivarelli, M. (2007). Entrepreneurship and the process of firms' entry, survival and growth. Industrial and Corporate Change, 16(3), 455-488.

Scarbrough, H., Swan, J., Amaeshi, K., \& Briggs, T. (2013). Exploring the role of trust in the deal-making process for early-stage technology ventures. Entrepreneurship: Theory and Practice, 37(5), 1203-1228.

Schoonjans, B., Van Cauwenberge, P., \& Bauwhede, H. (2013). Formal business networking and SME growth. Small Business Economics, 41, 169-181.

Schott, T., \& Jensen, K. (2016). Firms' innovation benefiting from networking and institutional support: A global analysis of national and firm effects. Research Policy, 45, 1233-1246.

Shane, S., \& Cable, D. (2002). Network ties, reputation, and the financing of new ventures. Management Science, 48(3), 364-381.

Sorrentino, M., Castaldi, L., \& Delli Paoli, A. (2015). Factors explaining the growth of small dedicated biotechnology firms: Evidence from Italy. Academy of Management Proceedings, 2015-1, 14305.

Stoian, M. C., Rialp, J., \& Dimitratos, P. (2017). SME network and international performance: Unveiling the significance of foreign market entry mode. Journal of Small Business Management, 55(1), 128-148.

Storper, M., \& Harrison, B. (1991). Flexibility, hierarchy and regional development: The changing structure of industrial production systems and their form of governance. Research Policy, 20, 407-422.

Svimez. (2015). Rapporto Svimez 2015 sull'economia del Mezzogiorno. Bologna: Il Mulino.

Teece, D. J. (2007). Explicating dynamic capabilities: The nature and microfoundations of (sustainable) Enterprise performance. Strategic Management Journal, 28(13), 1319-1350.

Teece, D. J., Pisano, G., \& Shuen, A. (1997). Dynamic capabilities and strategic management. Strategic Management Journal, 18(7), 509-533.

Teng, B. S. (2005). The emergence and popularization of strategic alliances: Institutional and entrepreneurial views. International Entrepreneurship and Management Journal, 1(1), 61-82. 
Teng, B. S., \& Das, T. K. (2008). Governance structure choice in strategic alliances. The Role of alliance objectives, alliance management experience, and international partners. Management Decision, 6(5), 725742.

Todeva, E. (2006). Business networks: Strategy \& structure. New York: Taylor \& Francis.

Tomlinson, P. R. (2010). Co-operative ties and innovation: Some new evidence for UK manufacturing. Research Policy, 39(6), 762-775.

Tommaso, S. (2009). Distretti e reti di imprese. Evoluzione organizzativa, finanza innovativa, valutazione mediante rating. Milano: Franco Angeli.

Tresca, R. (2016). The network manager and the governance of business networks: Comparison with managerial figures in management literature. International Journal of Social Ecology and Sustainable Development, 7(4), 35-46.

Tsai, W., \& Ghoshal, S. (1998). Social capital and value creation: The role of Intrafirm networks. The Academy of Management Journal, 41(4), 464-476.

Tunisini, A., Capuano, G., Arrigo, T., \& Bertani, R. (2013). Contratto di rete. Lo strumento Made in Italy per integrare individualità e aggregazione. Milano: Franco Angeli.

Uzzi, B. (1999). Embeddedness in the making of financial capital: How social relations and networks benefit firms seeking financing. American Sociological Review, 64, 481-505.

Vanhaverbeke, W., Gilsing, V., Beerkens, B., \& Duysters, G. (2009). The role of alliance network redundancy in the creation of core and non-core technologies: A local action approach. Journal of Management Studies, 46, 215-244.

Venkatraman, N., \& Lee, C. H. (2004). Preferential linkage and network evolution: A conceptual model and empirical test in the US video game sector. The Academy of Management Journal, 47(6), 876-892.

Verschoore, J. R., Wegner, D., \& Balestrin, A. (2015). The evolution of collaborative practices in small-firm networks: A qualitative analysis of four Brazilian cases. International Journal of Management Practice, $8(2), 152-168$.

Wang, H., Zhao, J., Li, Y., \& Li, C. (2015). Network centrality, organizational innovation, performance: A meta-analysis. Canadian Journal of Administrative Sciences, 32(3), 146-159.

Watson, J. (2007). Modeling the relationship between networking and firm performance. Journal of Business Venturing, 22, 852-874.

Watson, J. (2011). Networking: Gender differences and the association with firm performance. International Small Business Journal, 30(5), 536-558.

Wernerfelt, B. (1984). A resource-based view of the firm. Strategic Management Journal, 5(2), 171-180.

Wernerfelt, B. (1995). The resource-based view of the firm: Ten years after. Strategic Management Journal, 16(3), 171-174.

Williamson, O. E. (1975). Markets and hierarchies. Analysis and antitrust implications. New York: The Free Press.

Williamson, O. E. (2002). The theory of the firm as governance structure: From choice to contract. Economic Perspective, 3(16), 171-196.

Zaheer, A., \& Bell, G. (2005). Benefiting from network position: Firm capabilities, structural holes, and performance. Strategic Management Journal, 26(9), 809-825.

Zaheer, A., McEvily, B., \& Perrone, V. (1998). Does trust matter? Exploring the effects of Interorganizational and interpersonal trust on performance. Organization Science, 9(2), 141-159.

Zineldin, M., \& Dodourova, M. (2005). Motivation, achievements and failure of strategic alliances: The case of Swedish auto-manufacturers in Russia. European Business Review, 17(5), 460-470.

Zollo, M., \& Winter, S. G. (2002). Deliberate learning and the evolution of dynamic capabilities. Organization Science, 13(3), 339-339.

Zollo, M., Reuer, J. J., \& Singh, H. (2002). Interorganizational routines and performance in strategic alliances. Organization Science, 13(6), 701-713.

Publisher's note Springer Nature remains neutral with regard to jurisdictional claims in published maps and institutional affiliations. 